\title{
Infrastructure Concessions in Latin America
}

\author{
Government-led Renegotiations
}

\author{
J.Luis Guasch \\ World Bank and University of California, San Diego \\ Jean-Jacques Laffont \\ University of Toulouse and University of Southern California \\ Stéphane Straub1 \\ University of Edinburgh
}

World Bank Policy Research Working Paper 3749, October 2005

The Policy Research Working Paper Series disseminates the findings of work in progress to encourage the exchange of ideas about development issues. An objective of the series is to get the findings out quickly, even if the presentations are less than fully polished. The papers carry the names of the authors and should be cited accordingly. The findings, interpretations, and conclusions expressed in this paper are entirely those of the authors. They do not necessarily represent the view of the World Bank, its Executive Directors, or the countries they represent. Policy Research Working Papers are available online at http://econ.worldbank.org.

${ }^{1}$ Corresponding author. School of Economics, University of Edinburgh, William Robertson Building, 50 George Square, Edinburgh EH8 9JY, UK. Email: Stephane.straub@ed.ac.uk. We thank Emmanuelle Auriol, Jean-Paul Azam, Arnold Chassagnon, Denis Cogneau, Russell Davidson, Pierre Dubois, Antonio Estache, Vivien Foster, Guido Friebel, Jerry Hausman, Sylvie Lambert, Stéphane Luchini, Michel Lubrano, Brian Poi and Jozsef Sakovics, as well as seminar participants at University of Edinburgh, Paris LEA-DELTA, University of Toulouse, GREQAM-Marseille, the 2004 EC2 Econometrics of IO conference in Marseille and the 2005 workshop on Auctions and Public Service Procurement at Paris 1 for helpful comments. 


\begin{abstract}
This paper complements the existing knowledge in the renegotiation literature on infrastructure concessions by analyzing government-led renegotiations. We first propose a multiple-period theoretical framework in which both Pareto improving and rent shifting renegotiations at the initiative of the government can occur. We then perform an empirical analysis based on a sample of 307 water and transport projects in five Latin American countries between 1989 and 2000. While some of the main insights from the previous literature are unchanged, for example concerning the importance of having a regulator in place when awarding concessions and the fragility of price cap regulatory schemes, there are also significant differences as predicted by the model, in particular with respect to the effect of investment and financing, as well as the corruption variables. We provide additional evidence showing that a good regulatory framework is especially important in contexts with weak governance and political opportunism.
\end{abstract}




\section{Introduction}

The 1990s witnessed a spectacular wave of private sector participation in infrastructure. Considering the four infrastructure sectors, transport, water, energy and telecommunications, US\$ 754billion was invested between 1990 and 2001 in around 2,500 projects with private sector participation in developing countries (see Harris, 2003). Of this, 48\% was directed to Latin America and the Caribbean, where these investments were in their majority related to the sale or concessioning of existing assets. Due to political and sometimes constitutional and legal reasons making outright privatization difficult, concessions have been the salient choice for private sector participation. They have accounted for $67 \%$ of all projects worldwide, being moreover the almost exclusive form of private sector involvement in water and transport, as well as some energy projects. A concession provides its holder the right to operate a service for a limited period of time (usually 20 to 30 years), at the end of which all the assets revert back to the government. The concessionaire is responsible for all investments as well as any other obligations specified in the contract in exchange for the right to the cash-flow of the users' payments.

However, by the early 2000s, a growing disenchantment with private sector involvement in general and concessions in particular has forced governments to slow down or stop the program and reform process in practically all countries in Latin America. Annual flows of investment are well below their 1997 peak. There are clearly doubts that stem from the slow pace of improvements (at least relative to build-up expectations), and the frequent conflicts that arose in the past between contractual parties, with a large number of projects having been renegotiated or taken over by governments (see Guasch, 2004, for a detailed description of the Latin American experience with concessions).

In line of its relevance and impact, the motivation of this research is to identify the triggers and determinants of renegotiation. In principle, renegotiation, when properly used, can enhance welfare. However high incidence does raises concerns about the validity of the model. In particular, renegotiation can reduce or eliminate the benefits of competitive bidding. If bidders believe that renegotiation is likely, their incentives and bids will probably be affected, and the auction might not select the most efficient provider, but the most skilled at renegotiation ${ }^{1}$.

\footnotetext{
${ }^{1}$ Other costs linked to renegotiations are discussed below.
} 
In a previous paper that focused on the analysis of firm-led renegotiation (Guasch, Laffont and Straub, 2003, referred to hereinafter as GLS), we analyzed a Latin American data set from the World Bank, with 307 concession projects in the sectors of transport and water, in five countries (Argentina, Brazil, Chile, Colombia and Mexico) between 1989 and 2000. We showed that more than half of these projects were renegotiated (162 out of 307) and very fast, on average 3.5 year after the signing of the contract. The paper focused on firm-led renegotiation and built a model of renegotiation that included contract characteristics, regulatory and institutional environment, as well as external shocks. The empirical analysis there confirmed most of the predictions of the model and yielded interesting policy implications, especially with respect to the importance of having a regulatory body in place at the time of awarding a concession and of choosing the appropriate regulatory regime. We showed that the mode of regulation matters and that price caps, which have been the dominant choice of policy makers in Latin America, suffer from a great fragility to shocks and trigger significant renegotiation. As a consequence, there is a growing pragmatic tendency to advocate the abandonment of price cap regulation, a synonym for the higher risk of renegotiation and higher cost of capital, and the return to an hybrid type of regulation, including some elements of rate of return (see for example Estache, Guasch and Trujillo, 2003).

The present paper complements GLS by looking at government-led renegotiations. Private sector participation has often been accompanied by sector restructuring prior to the transfer and by the implementation of a legal and regulatory framework. This is meant to protect investors from arbitrary and politically motivated intervention from the government, to protect users from the abuse of the monopoly or dominant position of the new private operators, and also to protect the competitive new entrants from a dominant incumbent operator. Quite often, the required and necessary investments are highly specific "sunk" type costs that cannot easily be recouped if the economic or political atmosphere deteriorates or if the operator were to discontinue operations. This may tempt governments to behave opportunistically and take ex post regulatory actions that expropriate the available quasi-rents.

Typical scenarios are a government or a mayor in the case of water concessions (mayors have exclusive jurisdiction on water operations) deciding in a unilateral fashion to cut tariffs or not to honor agreed tariff increases during a re-election campaign to secure popular support. Another not uncommon scenario is a new administration deciding not to honor the tariffs increase 
stated in the concession contract granted by the previous administrations. Examples, to mention only a few (see Guasch 2004 for more detailed evidence), include recent popular unrest in Bolivia, which led in January 2005 to the cancellation of the La Paz and El Alto water concession, led by the French multinational Suez Lyonnaise des Eaux. As of 2005, most of the concessions awarded in Argentina prior to the 2001 crisis are still undergoing protracted renegotiation processes. Conflict arose as the government converted the dollar-denominated rates to devalued pesos despite contract clauses that contemplated indexation to the dollar and US inflation, and refused any subsequent significant rate adjustment. Despite 62 firms' suits before the World Bank's International Centre for Settlement of Investment Disputes, Argentina has been very slow in responding to those challenges, arguing the need to protect the interest of the Argentinian people. It has also argued that international arbitrage decisions should be reviewed by local judicial courts, despite the country's agreement to abide to international arbitration, under bilateral investment treaties signed by the government of Carlos Menem in the $1990 \mathrm{~s}^{2}$. Similarly, the Limeira water concession in Brazil was denied tariffs adjustment that was supposed to be automatic according to the contract. The local mayor argued that the contract, signed by a previous administration, was unfair and compromised the municipality's long term interests. Similar behavior plagued the Tucuman water and sanitation contract in Argentina. In 1995, a new local government took office and sought to limit previously agreed upon tariff increases. This finally led the concessionaire to abandon the concession in 1996. In the toll road concession in Pernambuco, Brazil, the regional government decided to cut the tariffs unilaterally shortly before elections. Sometimes, lack of commitment shows up at even earlier stages, like in the case of the 1997 Ukranian cellular telephone contract or the 1999 Matarani port concession in Peru, where the rules of the tender were changed unilaterally in the awarding period (introducing an additional annual fee in one case, shortening the duration of the concession from 30 to 15 years in the other one).

In most cases, the social costs of such renegotiations are likely to be high. The knowledge by potential investors that the temptation exists to expropriate investments ex post may discourage investment in the first place or it might require an additional risk premium in the form of bigger tariffs or

\footnotetext{
${ }^{2}$ See The Economist, March 17, 2005, and IPS-Inter Press Service, April 11, 2005, "Economy-Argentina, the Battle that Lies Ahead" at http://www.ipsnews.net/index.asp.
} 
smaller transfer price. That possibility is the main source of regulatory risk, impacting costs of capital and, consequently, tariffs levels. The extent of that added regulatory risk component is not trivial. The estimates, depending on country and sector, range from 2 to 6 percentage points to be added to the cost of capital (Guasch and Spiller 1999), with a substantial impact. For example an increase of $5 \%$ in the cost of capital leads to a reduction of the offered transfer fee or sale price of about $35 \%$ or equivalently it requires an increase in tariffs of about 20\%. In the water concession in the city of Buenos Aires, the regulator granted a tariff increase of $3.5 \%$ for each percentage point increase on the cost of capital.

There is also ample anecdotal evidence documenting other potential costs, including large scale service disruption, failure to meet coverage expansion targets (e.g. the airport concession in Lima, Peru, awarded in 2001 and renegotiated in 2003, and the Buenos Aires water concession, abandoned two years into the contract after unsuccessful renegotiation attempts) and cost pass-through to users or taxpayers in excess of initial agreements (examples include the Buenos Aires water concession discussed above, as well as most toll road schemes, like the ones in Colombia and in the Dominican Republic). An extreme example is the Mexican toll road program, comprising 52 highways built under private concessions in the early 1990s, which was finally bailed out by the government in 1997 at an estimated cost of between US $\$ 7$ to 12 billion ( 1 to $1.7 \%$ of GDP) $)^{3}$.

From a theoretical point of view, government-led renegotiations represent a different challenge than firm-led ones. Indeed, if firms have private information and anticipate opportunistic behavior by the government, for example because it is not able to commit not to renegotiate, they may want to hide their information to protect future rent. The resulting ratchet effect (see for example Laffont and Tirole, 1993) may give rise to extremely complex situations. We address this issue by extending the GLS framework to two or more periods, thus explicitly incorporating political cycle considerations in the analysis. We show that the condition of the static model, ensuring that the good firm does not want to mimic the bad one and renegotiate, carries over to the dynamic framework. In this case, the opportunity for Pareto improving renegotiations at the initiative of the government exists in the second period, with the first period outcome representing the status quo in this new renegotiation.

\footnotetext{
${ }^{3}$ See Guasch, 2004, for details and discussion on these and other cases.
} 
Moreover, to account for the possibility of opportunistic behavior by governments, we introduce the possibility that, when a new government is elected, there is a small chance that it expropriates the rents secured by the firm in the initial contract. If the probability of this outcome is not too large, no ratchet effect occurs and we have a model displaying both Pareto improving and rent shifting government-led renegotiations. If it is large, there is ratchet effect or no investment at all, so no renegotiation occurs.

As a result, we obtain an equation for the probability of government-led renegotiation that allows us to derive theoretical predictions for the main variables in our analysis. While the direction of the effects are unchanged for a number of variables, like shocks or the existence of a regulator, theory leads to expect opposite effects in the case of the variables affecting the status quo of the parties in an eventual renegotiation, namely the financing variables (investment requirements and private financing) and institutional quality.

We then present empirical results based on the same sample as in GLS, using as dependent variable the occurrence of a renegotiation at the initiative of the government. From the empirical viewpoint, a number of differences with firm-led renegotiations are also to be expected. One open question is the influence of price cap regulation. Firms' calls for renegotiation were the intuitive outcome when the cap appeared to be too restrictive. Here, we could expect a reverse effect, in the sense that governments would like to renegotiate caps that proved too generous and leave excessive profits to the firms (the opportunistic calls). However, it could also be the case that governments concerned about the continuity of service or the realization of planned investments would step in when firms are making losses, resulting in a similar effect of price cap on firm-led and government-led renegotiations. Another aspect of interest is the behavior of variables affecting the status quo of the parties in a renegotiation, in particular the financing variables, which effect should be the opposite as with firm-led renegotiation. Finally, it is not clear how institutional quality variables should behave, as a number of channels involving the quality of the bureaucracy and the possibility of capture can be envisioned. Indeed, corruption can be expected to give rise to hidden and non-transparent renegotiations (e.g. the Mexican Northeast Railway concession or the generic case of highway franchising in Latin America, discussed in Engel, Fischer and Galetovic, 2003), or on the contrary to produce ex ante biased awards through direct adjudication or the manipulation of insider information, resulting in a situation in which concessionaire and government representatives share excessive rents and have little incentive to 
renegotiate (Rose-Ackerman, 1999).

The results on both the importance of having a regulator and the fragility of price caps are unchanged with respect to firm-led renegotiation. On the other hand, consistently with the theoretical predictions, investment and financing variables have reversed effect, as does corruption. Moreover, we present additional evidence showing that the role of an experienced and independent regulator is especially important in contexts characterized by weak governance and high likelihood of political expropriation. This is certainly an important result, as it shows that strong and experienced regulators are likely to act as barriers against political opportunism, especially when they are present at early stages of concessions' lives.

Section 2 below spells out the model and discusses potential extensions, Section 3 presents the data and the empirical evidence, and Section 4 concludes.

\section{Theory: Government-led Renegotiations}

\subsection{Political Cycle}

To account for the possibility that at some point during the life of the project, the regulatory body may propose to the firm a renegotiation of the initial contract, we explicitly introduce political cycle considerations.

Consider that the contract that will be described below is signed for two periods ${ }^{4}$. At the beginning of the second period (time $t=2$ ), elections take place and the incumbent government is reelected with exogenous probability $q$. With probability $1-q$, a new government is elected and then remains in power throughout the second period. The reason to consider the probability of a political change as exogenous is that regulatory issues are unlikely to be pivotal in shaping the outcome of elections ${ }^{5}$.

\footnotetext{
${ }^{4}$ As will become clear, this could be extended to 3 or more periods without changes. Note that in our sample more than $97 \%$ of the contracts are signed for between 20 and 30 years.

${ }^{5}$ This assumption, introduced for example by Besley and Coate (2003) in the context of US data, seems reasonable in normal electoral processes. In recent Peruvian events, widespread popular opposition to the privatization of electricity generation in Arequipa, in 2002, can be deemed partly responsible for the resignation of the cabinet of President Toledo in 2003, although the president himself remained in power and no elections were held.
} 
Moreover, we assume that the initial government has the ability to engage in long term contracting that goes beyond its own term in power. We also assume it can commit itself to its policy (commit not to renegotiate), so that if it remains in power, no government-led renegotiation offer is made. However, when a change of majority occurs, the new government has the ability to renegotiate, with the initial contract representing the status quo utility level of the firm. Thus, the firm may refuse the new contract it is offered and carry on with the initial one. As discussed in Aubert and Laffont (2002), most constitutions grant governments, acting as representative of the State, the ability to commit to long term contractual agreements, as is the case when concession contracts lasting for several decades are drafted. However, it also gives new governments the ability to modify to some extent the agreements made by their predecessors. This provides for the necessary flexibility to modify bad agreements, or those that have become not suitable anymore due either to changes in the preferences of the parties or of the population as a whole, or to shift in environmental parameters. So, a newly elected government makes a take-it-or-leave-it renegotiation offer to the firm, but has to stick to the original contract if its offer is turned down.

Additionally, we assume that with a small probability $\mu$, the newly elected government does not respect its legal obligations and it reneges on the outstanding contract, in effect expropriating the firm's rent. In this context, it is intuitive to think about the probability of expropriation as a shortcut to the country's level of political risk, which is known in expectation by the investing firm and guides its decision to apply for the concession ex ante. It therefore makes sense to keep it exogenous, as it is likely to depend on factors lying outside the scope of a given concession ${ }^{6}$.

\subsection{The Contract}

We consider the concession of a natural monopoly which, in addition to a common knowledge necessary sunk investment, or fixed cost, $F$, has a

\footnotetext{
${ }^{6}$ While political risk assessment is widely used by firms investing in developing countries, some extreme and unforeseeable cases of commitment breakdown seem to be driven more by governments' inability to manage shocks, as the following quote from Harris (2003) suggests: "For their part, some investors over-estimated the ability of governments to manage the reform process and hence honor their tariff, and other, commitments. In some cases, such as in Indonesia and Argentina, this extended to judgments about the ability of the government to sustain stable macroeconomic policies."
} 
variable cost function ${ }^{7}$ :

$$
C=(\beta-e) q .
$$

where $q$ is the production level, $\beta$ is a cost parameter known only by the firm (adverse selection) in $\{\beta, \bar{\beta}\}$ with $\nu=\operatorname{Pr}(\beta=\beta)$ and $e$ is an effort variable (moral hazard) which decreases cost, but creates to the manager a disutility $\Psi(e)$ with $\Psi^{\prime}>0, \Psi^{\prime \prime}>0, \Psi^{\prime \prime \prime} \geq 0$.

Consumers derive utility $S(q), S^{\prime}>0, S^{\prime \prime}<0$ from the consumption of the good. With $p($.$) being the inverse demand function and \hat{t}$ the transfer from the regulator to the firm, in the simple version of the GLS model, we can write the firm's net utility as:

$$
U=\hat{t}+p(q) q-(\beta-e) q-F-\Psi(e) .
$$

Assume that cost is ex post observable by the regulator as well as the price and the quantity. Making the accounting assumption that revenues and cost are incurred by the regulator, who pays a net transfer $t=\hat{t}+p(q) q-(\beta-$ $e) q-F$, the participation constraint of the firm becomes:

$$
U=t-\Psi(e)=t-\Psi(\beta-c) \geq 0,
$$

where, from (1), we substitute $e$ by $\beta-c$, with $c=\frac{C}{q}$.

The transfer $\hat{t}$ is financed through taxes, which give rise to a cost of public funds $1+\lambda, \lambda>0$, so consumers' net utility is given by:

$$
V=S(q)-p(q) q-(1+\lambda) \hat{t} .
$$

Utilitarian social welfare is then given by the sum of consumers' surplus and the firm utility, here with equal weight of 1 for both:

$$
\begin{aligned}
\widehat{W} & =U+V \\
& =S(q)+\lambda p(q) q-(1+\lambda)((\beta-e) q+F+\Psi(e))-\lambda U .
\end{aligned}
$$

Note that the regulator dislikes leaving a rent to the firm, which occurs as long as the weight of its rent is lower that $1+\lambda$.

\footnotetext{
${ }^{7}$ On the basic model, see the discussion and references in GLS.
} 
Under complete information, the maximization of social welfare leads to ${ }^{8}$ :

$$
\begin{aligned}
S^{\prime}\left(q^{*}\right)+\lambda\left(p^{\prime}\left(q^{*}\right) q^{*}+p\left(q^{*}\right)\right) & =(1+\lambda)\left(\beta-e^{*}\right) \\
\Psi^{\prime}\left(e^{*}\right) & =q^{*} \\
U & =0
\end{aligned}
$$

and we denote $\underline{q}^{*}, \underline{e}^{*}, \underline{U}^{*}$ and $\bar{q}^{*}, \bar{e}^{*}, \bar{U}^{*}$ the solutions corresponding to $\underline{\beta}$ and $\bar{\beta}$ respectively.

This solution equates the marginal disutility of effort $\Psi^{\prime}(e)$ to its marginal social gain $q$, while leaving no rent to the firm because funds are socially costly $(\lambda>0)$.

In what follows, we assume that the regulator observes neither the effort level $e$ nor the cost parameter $\beta$. However, he is able to offer a contract to the firm before it discovers its type ${ }^{9}$ (see Figure 1 for the timing).

$\begin{array}{cccc}\begin{array}{c}\text { The regulator } \\ \text { offers the } \\ \text { regulatory } \\ \text { contract }\end{array} & \begin{array}{c}\text { The firm accepts } \\ \text { or not the contract }\end{array} & \begin{array}{c}\text { The firm discovers } \\ \text { its type } \beta\end{array} & \begin{array}{c}\text { Production and } \\ \text { transfer take } \\ \text { place }\end{array} \\ & & \text { Time }\end{array}$

Figure 1: Timing

From (3), the observability of cost reduces the problem to a simple adverse selection problem ${ }^{10}$. From the Revelation Principle, there is no loss of generality in restricting the analysis to direct revelation mechanisms $\{(\underline{t}, \underline{c}),(\bar{t}, \bar{c})\}$. For each message $\tilde{\beta}=\beta$ or $\tilde{\beta}=\bar{\beta}$, the welfare maximizing regulatory contract specifies an average cost to achieve and a net transfer from the regulator, as well as a production level $\underline{q}$ (or $\bar{q}$ ) and a total $\operatorname{cost} \underline{C}$ (or $\bar{C}$ ), compatible with $\underline{c}$ (or $\bar{c})$ (between which the firm is indifferent).

\footnotetext{
${ }^{8}$ We make the appropriate assumptions on $S($.$) so that W$ is strictly concave in $(q, e)$. For more details and motivations about the various assumptions, see Laffont and Tirole (1993).

${ }^{9}$ This timing assumption is not crucial, as is shown in GLS, but simplifies the presentation of the model. Introduction of a firm's limited liability constraint (see below) de facto takes us back to a standard ex post contracting framework.

${ }^{10}$ See Laffont and Martimort (2002), Chapter 7, on "false moral hazard" models.
} 
The direct revelation mechanism must satisfy the incentive constraints:

$$
\begin{aligned}
\underline{U} & =\underline{t}-\Psi(\underline{\beta}-\underline{c}) \geq \bar{t}-\Psi(\underline{\beta}-\bar{c}) \\
\bar{U} & =\bar{t}-\Psi(\bar{\beta}-\bar{c}) \geq \underline{t}-\Psi(\bar{\beta}-\underline{c}),
\end{aligned}
$$

which can be rewritten:

$$
\begin{aligned}
& \underline{U} \geq \bar{U}+\Phi(\bar{e}) \\
& \bar{U} \geq \underline{U}-\Phi(\underline{e}+\Delta \beta),
\end{aligned}
$$

with $\Phi(e)=\Psi(e)-\Psi(e-\Delta \beta), \Phi^{\prime}>0, \Phi^{\prime \prime}>0$.

Finally, the firm's participation constraint is written ex ante (before it discovers its type):

$$
\nu \underline{U}+(1-\nu) \bar{U} \geq 0 .
$$

Before writing the regulator's maximization problem, we discuss the characteristics of the case where the firm is protected by limited liability, i.e. $U \geq 0$, as in Section 2.5. of GLS. As explained below, this is meant to ensure that the firm is able to repay the loan taken from the bank to finance part or all of the sunk cost. Additionally, the firm owns assets which can be used as collateral if it incurs some debt. The sunk investment has to be made before producing, and financing may take two forms. The firm relies on bank financing for the initial investment ${ }^{11}$, but if private financing fails to cover the needs, the government provides the complement. We introduce the following notations:

$A$ is the firm's assets needed for the project, $F$ is the necessary sunk investment and $K$ is the part financed by banks' loans, with $K \in[0, F]$. If $K=0$, we have complete government financing, while $K=F$ corresponds to exclusive private financing. For intermediate values of $K$, the government finances a share $F-K$ of the investment. The interest rate on the eventual loan is $r$.

Considering the required repayment $K$, the firm's utility level becomes:

$$
U=\hat{t}+p(q) q-(\beta-e) q-(1+r) K-\Psi(e) .
$$

Thus, the regulator includes the constraint that the bank must always be paid back in his program.

\footnotetext{
${ }^{11}$ See GLS for a discussion on the form of the limited liability constraint as well as issues related to the nature of the bank, the welfare function and to multiparty bargaining.
} 
Rewriting it in terms of the variables $(q, e, U)$ rather than $(q, c, U)$, let us denote $W(q, e, \beta)$ the complete information ex post social welfare for a production level $q$ and an effort level $e$ when the efficiency parameter is $\beta$, i.e.:

$$
W(q, e, \beta)=S(q)+\lambda p(q) q-(1+\lambda)((\beta-e) q+F+r K+\Psi(e)) .
$$

We also assume that $A<F$, so that the firm is able to repay only a share of its debt in case of failure. Two cases arise. If $K<A$, the bank gets $K$, while the government gets the remainder $A-K$, for a net loss $F-A$. If $K>A$, the bank gets $A$ while the government gets nothing. Summarizing, the status quo payoffs write:

$$
(-A,-H-F+\max (K, A)) .
$$

Note that the level of $K$ will affect the status quo payoff of the government in case of renegotiation, and that there is an additional term $H$, capturing other costs like loss of reputation. We assume that a firm attempts to renegotiate when its ex post utility level after renegotiation is higher than the utility level specified in the contract $\left(\bar{U}^{E}>\bar{U}_{1} \geq 0\right)$. However, with probability $\pi(x)$, the regulator is nevertheless able to implement the initial contract. This depends on the level of expenses $x$ incurred to finance the functioning of an enforcement mechanism, with $\pi(0)=0, \lim _{x \rightarrow \infty} \pi(x)=1, \pi_{x}>0$, $\pi_{x x}<0$.

With probability $1-\pi(x)$, a renegotiation happens. We model it with the Nash bargaining solution and assume that renegotiation is costly and reduces aggregate social welfare (this is intrumented by the parameter $\delta \in(0,1)$ ), for example because it takes time ${ }^{12}$. Moreover, as we discuss extensively in the following section, we make appropriate assumptions so that the efficient type firm never wants to renege on its contract. Therefore, costly bargaining takes place under complete information, only when $\beta=\bar{\beta}$.

With the possibility of renegotiation and the disagreement point now given above, ex post bargaining yields:

$$
\bar{U}^{E}=\frac{\delta W\left(\bar{q}^{*}, \bar{e}^{*}, \bar{\beta}\right)+H+F-\max (K, A)-\lambda A}{2 \lambda} .
$$

\footnotetext{
${ }^{12}$ If global social welfare is not reduced by renegotiation, building an enforcement institution has no purpose.
} 
Events unfold as follows. A firm discovering to be a bad type $\bar{\beta}$ intends to renegotiate the contract ex post. With probability $\pi(x)$ it faces tough enforcement and is obliged to carry on with the project, while with probability $1-\pi(x)$, it succeeds in forcing a renegotiation. Moreover, we assume that with some (small) positive probability $P$ the renegotiation breaks down, yielding the status quo payoffs. Anticipating the outcome of the renegotiation, it is optimal for the regulator to modify its offer ex ante. Call $\underline{U}_{1}$ and $\bar{U}_{1}$ the modified rents, with the resulting probabilities:

$$
\begin{aligned}
\operatorname{Pr}\left(U=\underline{U}_{1}\right) & =\nu \\
\operatorname{Pr}\left(U=\bar{U}_{1}\right) & =(1-\nu) \pi(x) \\
\operatorname{Pr}\left(U=\bar{U}^{E}\right) & =(1-\nu)(1-\pi(x))(1-P) \\
\operatorname{Pr}(U=-F) & =(1-\nu)(1-\pi(x)) P .
\end{aligned}
$$

The program of the regulator then becomes:

$$
\begin{aligned}
& \max \nu\left[W(\underline{q}, \underline{e}, \underline{\beta})-\lambda \underline{U}_{1}\right]+(1-\nu) \pi(x)\left[W(\bar{q}, \bar{e}, \bar{\beta})-\lambda \bar{U}_{1}\right] \\
& +(1-\nu)(1-\pi(x))(1-P)\left[\delta W\left(\bar{q}^{*}, \bar{e}^{*}, \bar{\beta}\right)-\lambda \bar{U}^{E}\right] \\
& +(1-\nu)(1-\pi(x)) P[-H-F+\max (K, A)]-(1+\lambda) x
\end{aligned}
$$

s.t.

$$
\begin{aligned}
\nu \underline{U}_{1}+(1-\nu) \pi(x) \bar{U}_{1} & \\
+(1-\nu)(1-\pi(x))(1-P) \bar{U}^{E} & \\
-(1-\nu)(1-\pi(x)) P A & \geq 0 \\
\underline{U}_{1} & \geq \bar{U}_{1}+\Phi(\bar{e}) \\
\bar{U}_{1} & \geq \underline{U}_{1}-\Phi(\underline{e}-\Delta \beta) \\
\underline{U}_{1} & \geq 0 \\
\bar{U}_{1} & \geq 0,
\end{aligned}
$$

where (19) is the participation constraint written in expected terms and including the possibility of renegotiation, and (20) and (21) (resp. (22) and (23)) are the incentives (resp. participation) constraints of the good and the bad types.

The limited liability constraint of the bad type (23) and either the incentive constraint of the good type (20) or the participation constraint (19) 
are binding. Using the fact that $\bar{U}_{1}=0$, we can summarize the last two constraints by:

$$
\underline{U}_{1} \geq \max \left\{\Phi(\bar{e}), \frac{(1-\nu)(1-\pi(x))\left[P A-(1-P) \bar{U}^{E}\right]}{\nu}\right\} .
$$

Since renegotiation happens only if $\bar{U}^{E} \geq 0$, and $P$ is small, the second term in brackets is negative, so it is the incentive constraint (20) that binds. Substituting the values of $\underline{U}_{1}, \bar{U}_{1}$ and $\bar{U}^{E}$, the objective function becomes:

$$
\begin{aligned}
& \max \nu[W(\underline{q}, \underline{e}, \underline{\beta})-\lambda \Phi(\bar{e})]+(1-\nu) \pi(x)[W(\bar{q}, \bar{e}, \bar{\beta})] \\
& +(1-\nu)(1-\pi(x))(1-P)\left[\frac{\delta W\left(\bar{q}^{*}, \bar{e}^{*}, \bar{\beta}\right)-H-F+\max (K, A)+\lambda A}{2}\right] \\
& +(1-\nu)(1-\pi(x)) P[-H-F+\max (K, A)]-(1+\lambda) x .
\end{aligned}
$$

So the good firm produces the first best level $\left(\underline{q}^{E}=\underline{q}^{*} ; \underline{e}^{E}=\underline{e}^{*}\right)$, while the effort and output levels of the bad type are distorted to reduce the expected rent of the good firm:

$$
\Psi^{\prime}\left(\bar{e}^{L}\right)=\bar{q}^{L}-\frac{\lambda}{1+\lambda} \frac{\nu}{(1-\nu) \pi\left(x^{L}\right)} \Phi^{\prime}\left(\bar{e}^{L}\right)
$$

Note that the term $\pi\left(x^{L}\right)$ at the denominator implies a stronger distortion than the standard second best ex post contracting level $\left(\bar{q}^{S B}, \bar{e}^{S B}\right)$.

Finally, the level of enforcement is now given by:

$$
=\frac{(1-\nu) \pi^{\prime}\left(x^{L}\right)}{\left[W\left(\bar{q}^{L}, \bar{e}^{L}, \bar{\beta}\right)-\delta\left(\frac{1-P}{2}\right) W\left(\bar{q}^{*}, \bar{e}^{*}, \bar{\beta}\right)\right]+\left(\frac{1+P}{2}\right)\left[\delta W\left(\bar{q}^{*}, \bar{e}^{*}, \bar{\beta}\right)+H+F-\max (K, A)\right]-(1-P) \lambda A} .
$$

\subsection{Two Periods}

\subsubsection{Pareto Improving Renegotiation}

In second period, a newly elected government (probability $1-q$ ) makes a takeit-or-leave-it renegotiation offer to the firm. If the firm accepts the offer, the 
contract is modified accordingly. If it rejects it, the original contract remains unaltered $^{13}$.

Given the possibility of political change, the initial government does not alter the contract it offers to the firm at time $t=1$, which is still characterized by the following menu:

$$
C=\left\{\left(\bar{q}^{L} ; \bar{e}^{L} ; \bar{U}^{1}=0\right)\left(\underline{q}^{E}=\underline{q}^{*} ; \underline{e}^{E}=\underline{e}^{*} ; \underline{U}^{1}=\Phi\left(\bar{e}^{L}\right)\right)\right\} .
$$

This follows straightforwardly from the fact that this government is not able to renegotiate the contract if it stays in power in the second period, nor is it able to shift the allocation of the rent across time ${ }^{14}$.

The key issue here is to determine whether the fact that a new government offers to renegotiate the original contract with probability $1-q$ will induce any strategic behavior from the firm in the first place. In other word, we need to determine whether they will be any ratchet effect.

This question boils down to the problem of whether the good type will have an interest in mimicing the bad type at $t=1$ in order to secure a better deal at $t=2$. Indeed, given the original contract, at $t=2$ the new government will only offer renegotiation to the bad type, proposing to raise the level of production $\left(\bar{q}^{L}\right)$ to the first best level $\bar{q}^{*}$, while maintaining its rent to the previous level $\left(\bar{U}^{1}=0\right)$. There is no room for renegotiation with the good type, as it is already producing the first best level $\underline{q}^{*}$ and would reject any proposal reducing its rent.

The analysis in the present case is greatly simplified by observing that the original contract is signed before the firm actually learns its type. Moreover, just after the initial agreement, the bad type firm actually intends to renegotiate its contract. Thus, the only way for a good firm to mimic a bad

\footnotetext{
${ }^{13}$ Such a renegotiation would be a mutually-agreed one, in contrast with the one provoked by the firm reneging on its contract against the government's will. We thus make the additional intuitive assumptions that, being desired by both parties, this renegotiation is less costly than the firm-led one. For simplicity, we normalize the cost in the present case to 1 . We could consider a cost $\widetilde{\delta}$ such that $\delta \leq \widetilde{\delta}<1$, with similar results overall. Moreover, note that none of the parties will want to make use of the officially financed enforcement mechanism (none of them would go to court to try to avoid renegotiation for example).

${ }^{14}$ This would only matter if the government were composed of stake-holders of the firm, so it would retain some benefit from the firm's rent even after leaving power. In this case, it may want to distort the original contract to modify the posterior renegotiation game between the firm and its successor (Aubert and Laffont, 2002).
} 
one would be to ask for a renegotiation at $t=1$. We have assumed that in the original model without political change, the good firm is worse off if mimicing the bad firm and renegotiating. In the case with limited liability but without political turnover, the equivalent of the condition, spelled out for the general model in footnote 13 of GLS, is:

$$
\begin{aligned}
\underline{U}_{1} \geq & \underline{U}^{E} \equiv \\
& \pi(x)\left[\bar{U}_{1}+\Phi\left(\bar{e}^{L}\right)\right]+\left(1-\pi\left(x^{L}\right)\right)(1-P)\left[\bar{U}^{E}+\Phi\left(\bar{e}^{L}\right)\right] \\
& +\left(1-\pi\left(x^{L}\right)\right) P[-A],
\end{aligned}
$$

where $\underline{U}^{E}$ denotes the utility of a good firm mimicing a bad firm and renegotiating and $A$ stands instead of $F$ as the firm's threat point. In the present case, we must consider the additional fact that at $t=2$ there is a probability $1-q$ that $\bar{q}^{L}$ be increased to the first best level $\bar{q}^{*}$, giving rise to a higher rent for a cheating firm. We show in the Appendix the shape of the modified condition. The most stringent constraint arises as $q=0$, and this condition becomes:

$$
\begin{aligned}
& 2 \underline{U}_{1} \geq \\
& \pi(x)\left[\Phi\left(\bar{e}^{L}\right)+\Phi\left(\bar{e}^{*}\right)\right]+(1-\pi(x))(1-P) 2\left[\bar{U}^{E}+\Phi\left(\bar{e}^{*}\right)\right] \\
& +(1-\pi(x)) P[-A] .
\end{aligned}
$$

which is similar (in a two period framework) to the one in footnote 13 of GLS, and which we again assume is satisfied.

\subsubsection{Rent Shifting Renegotiation}

Consider now that with probability $\mu$, the newly elected government does not stand by its obligation to respect the status quo utility of the firm and expropriates its rent, as in the introductory example of an incoming administration deciding not to honor tariff adjustment committed by its predecessor. Two additional instances of renegotiation now occur. First, with probability $(1-q) \mu$, the government reneges on the good firm's contract and offers a new contract $\left(q^{*} ; \underline{e}^{*} ; 0\right)$. Second, when a firm-led renegotiation has succeeded in period 1, the bad firm enjoys a contract giving it a rent $\bar{U}^{E}$. Again, with 
probability $(1-q) \mu$, the government calls for a renegotiation and makes a take-it-or-leave-it offer involving a contract $\left(\bar{q}^{*} ; \bar{e}^{*} ; 0\right)$.

It is easy to see that the right hand side of (28) is not modified, as the production levels of the bad type firm remains the same in all cases and so do the associated good firm's rents. However, the left hand side changes as the utility that accrues to a good firm choosing the good contract at $t=1$ is now brought down to 0 with probability $(1-q) \mu$ at $t=2$. Condition (28) becomes:

$$
\begin{aligned}
& (2-\mu(1-q)) \underline{U}_{1} \geq \\
& \pi(x)\left[\Phi\left(\bar{e}^{L}\right)+\Phi\left(\bar{e}^{*}\right)\right]+(1-\pi(x))(1-P) 2\left[\bar{U}^{E}+\Phi\left(\bar{e}^{*}\right)\right] \\
& +(1-\pi(x)) P[-A] .
\end{aligned}
$$

If $\mu$ is small enough, this inequality is still verified ${ }^{15}$.

\subsection{Probability of Government-led Renegotiations}

Considering that the good type will not want to cheat, we show in Figure 2 below the tree of actions and the eventual occurrence of renegotiation.

Conditional on a political change, the probability of renegotiation at the initiative of the government is given by the sum of the probabilities to have a Pareto improving renegotiation (contract with a bad type firm that was successfully enforced $\left.(1-\nu) \pi\left(x^{L}\right)(1-q)\right)$ and a rent-shifting renegotiation (contract with a good firm, probability $\nu(1-q) \mu$, as well as renegotiated contract with a bad type firm $\left.(1-\nu)\left(1-\pi\left(x^{L}\right)\right)(1-P)(1-q) \mu\right)$. This can be rewritten:

$$
\begin{aligned}
& \operatorname{Pr}(\text { Govt-led renegotiation })= \\
& (1-q)[\mu-(1-\nu) P \mu+(1-\nu)(1-(1-P) \mu) \pi(x)] .
\end{aligned}
$$

The important implication of (30) is that any variable of the model affecting the enforcement probability $\pi(x)$, either directly, like institutional

\footnotetext{
${ }^{15}$ We could introduce the possibility that at $t=2$ the expropriated firm recurs to the enforcement mechanism (e.g. the court) financed previously and manages to have the initial contract enforced with probability $\pi(x)$. We abstract from this complication, as the qualitative results would be similar, with an additional term $1-\pi(x)$ on the left hand side of (29), making it even easier to be satisfied.
} 
variables (see below), or indirectly, like the financing aspects that define the statu quo of the parties, will have opposite effect on the probability of government-led versus firm-led renegotiation.

Following the specifications introduced in GLS, the next subsection describes the introduction in the model of additional aspects like institutional quality and shocks and discusses their likely effect.

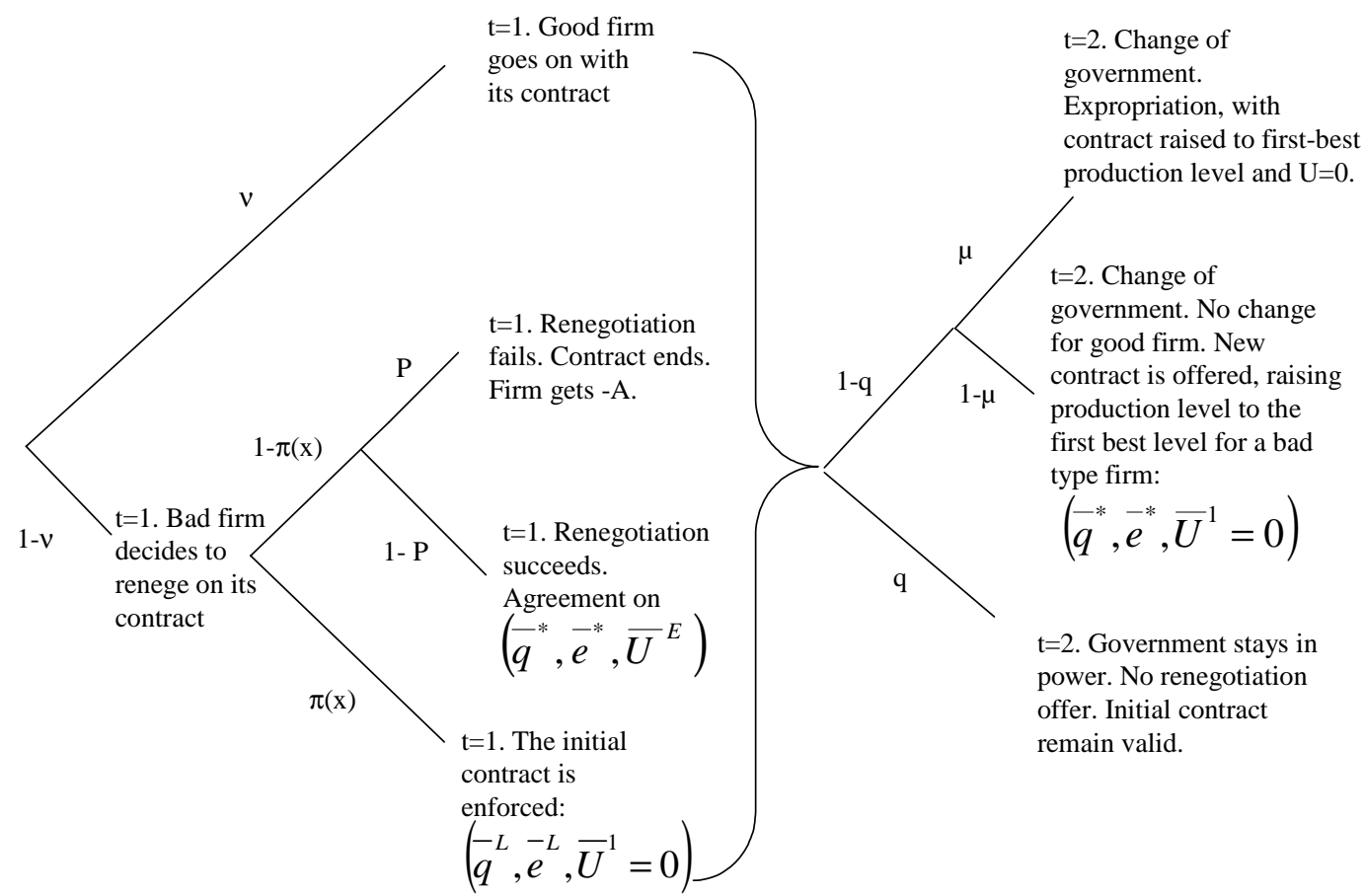

Figure 2

\subsection{Additional Aspects of the Model}

Exogenous Macroeconomic Shocks.

We assume that the distribution of firm's types is subject to an unanticipated noise, so that upon a shock $\varepsilon$, the probabilities of the enterprise being good or bad become $\{\nu+\varepsilon, 1-\nu-\varepsilon\}$. This is a shortcut to model a shock on either cost or demand of a fraction of the firms that allows us to take into account unanticipated events. The probability or renegotiation can now be 
written:

$$
\begin{aligned}
& \operatorname{Pr}(\text { Govt-led renegotiation })= \\
& (1-q)[\mu-(1-\nu-\varepsilon) P \mu+(1-\nu-\varepsilon)(1-(1-P) \mu) \pi(x)],
\end{aligned}
$$

which is decreasing in $\varepsilon$ if $P$ is small enough. Thus, as for firm-led renegotiation, positive shocks, such as an increase in demand or a favorable shift in relative prices of inputs or outputs, reduce the probability of governmentled renegotiation, while negative shocks (decrease in demand, cost shock) increase it.

\section{Institutional Quality}

Consider an enforcement function of the form $\theta \pi(x)$, where the parameter $\theta$ stands for the quality of institutions, with a $\theta$ closer to 1 corresponding to better institutions. Equation (26) can now be written:

$$
\begin{aligned}
& (1-\nu) \theta \pi^{\prime}\left(x^{L}\right) \\
& =\frac{1+\lambda}{\left[W\left(\bar{q}^{L}, \bar{e}^{L}, \bar{\beta}\right)-\delta\left(\frac{1-P}{2}\right) W\left(\bar{q}^{*}, \bar{e}^{*}, \bar{\beta}\right)\right]+\left(\frac{1+P}{2}\right)\left[\delta W\left(\bar{q}^{*}, \bar{e}^{*}, \bar{\beta}\right)+H+F-\max (K, A)\right]-(1-P) \lambda A} .
\end{aligned}
$$

Obviously, better institutions (more efficient bureaucracy, less corruption) translate into a higher level of investment in enforcement. Therefore, it will increase the probability of government-led renegotiation, as can be seen from equation (30), contrary to the case of firm-led renegotiation.

\subsection{Model Discussion}

Before turning to the empirical evidence, we discuss in this subsection the characteristics of government-led renegotiations in our model and briefly mention several potential extensions. We also make reference to the data used in the empirical analysis below to justify some of our theoretical choices.

Successive Renegotiations.

As it stands, one of the model implications is the possibility of having successive renegotiations, with a firm-led call at $t=1$, and a government-led call at $t=2$. To be precise, government-led renegotiations can happen in two different cases:

- As the first one in the life of the project ${ }^{16}$, with probability $(1-\nu) \pi(1-$ $q)+\nu(1-q) \mu$.

\footnotetext{
${ }^{16}$ Although not a first attempt to renegotiate in the case of a bad firm contract that was successfully enforced.
} 
- Following a previous firm-led renegotiation, with probability $(1-\nu)(1-$ $\pi)(1-P)(1-q) \mu$.

While we describe the data in more details in the next section, it is important to notice that this second case is not at odds with the stylized facts from the sample. There are indeed a few examples of consecutive renegotiations, like the water concession of Aguascalientes, Mexico, and some Argentinian concessions, including the Buenos Aires water concession ${ }^{17}$. However, this does not appear directly in our data set as, after a renegotiation, the projects actually leave the sample. They are sometimes brought back in as a new contract, when it is considered to be different enough from the previous one. Note, moreover, that the probability of having consecutive renegotiations remains small. This fits well the theoretical predictions, as the following calibration shows.

Considering the total number of projects (307) and the number of renegotiations initiated by the firm (53) and by the government (94) or the government and both (109), we get aggregate probabilities of renegotiation initiated by the firm of $17 \%$, and between 31 and $36 \%$ for the government (see Table 2 below).

Setting $\nu=0.4$ and the probability that the government remains in power to $q=0.5$, and calibrating the probability of enforcement $\pi(x)$ so that we get:

$$
\operatorname{Pr}(\text { firm-led renegotiation })=(1-\nu)(1-\pi(x))=0.17
$$

gives us a value of $\pi(x)=0.72$. We then get:

$$
\begin{aligned}
& \operatorname{Pr}(\text { Govt-led, first renegotiation }) \\
= & (1-\nu) \pi(x)(1-q)+\nu(1-q)=0.24,
\end{aligned}
$$

$\operatorname{and}^{18}$

$\operatorname{Pr}($ Govt-led, second renegotiation $)=(1-\nu)(1-\pi(x))(1-P)(1-q) \simeq 0.01$.

\footnotetext{
${ }^{17}$ Recently, a number of "second round" renegotiations happened in Argentina, after the devaluation and the economic crash at the end of 2001. These, however, exceed the time frame of our study.

${ }^{18}$ In our sample, 16 out of 162 cases of renegotiation led to the cancellation or the suspension of the project, so we use $P=0.1$. Moreover, we set $\mu=0.1$.
} 
These numbers fit relatively well the average probabilities shown above and show that the model supports a scenario in which government-led renegotiations following a previous renegotiation are only a small subset of all renegotiations at the initiative of the government.

Stationarity of the $\beta s$.

Another important point to consider is the question of the stationarity of the $\beta s$ in a multiperiod model. When there are successive renegotiations, it could be questioned whether such a stationarity assumption is realistic. Given the complexity of the model, however, we leave this issue for further analysis (see for example Laffont and Martimort, 2002) and content ourselves with observing that this problem is made less relevant by the fact that overall successive renegotiations are a rather small subset of the total.

Moreover, note that empirically this provides justification for the way projects are handled in our data base. They leave the sample when they are renegotiated, and enter as a new, different project if the concession carries on with significant modifications, thus avoiding the problems of confusing projects which distinct underlying technological characteristics.

\section{Empirical Evidence}

\subsection{The Data}

We use an original data set, developed by the World Bank, which describes the characteristics of nearly 1,000 concessions awarded in Latin American and Caribbean countries from 1982 to $2000^{19}$. As in GLS, and to keep results strictly comparable, we again focus on water and transport concessions in five countries (Argentina, Brazil, Chile, Colombia and Mexico), between 1989 and 2000. We have information on the general details of the projects (sector, activity, year of award, award criteria, size and duration of the concession), on the institutional and regulatory context, the type of regulatory framework put in place (price cap or rate of return), as well as the evolution of the main economic variables (growth, exchange rate, inflation) and the timing of national and local elections. Table 1 presents the full list and definitions of variables used in the analysis below and gives summary statistics.

\footnotetext{
${ }^{19}$ See GLS (2003) and Guasch (2004) for additional details on the data set.
} 
Table 1: List of variables, source and summary statistics

\begin{tabular}{|c|c|c|}
\hline Dummy variables, $1=$ Yes, $0=$ No. & Yes & No \\
\hline $\begin{array}{l}\text { Renegotiation: Dummy variable indicating whether there was or not a } \\
\text { renegotiation of the concession contract. }\end{array}$ & $162(52.8 \%)$ & $145(47.2 \%)$ \\
\hline Renegotiation initiated by the firm & $53(17.3 \%)$ & $254(82.7 \%)$ \\
\hline Renegotiation initiated by the government & $94(30.6 \%)$ & $213(69.4 \%)$ \\
\hline Renegotiation initiated by both & $15(4.9 \%)$ & $292(95.1 \%)$ \\
\hline $\begin{array}{l}\text { Existence of regulatory body: Dummy variable indicating whether there was or not } \\
\text { a regulatory body at the time of the concession first coming into operation. }\end{array}$ & $180(58.6 \%)$ & $127(41.4 \%)$ \\
\hline $\begin{array}{l}\text { Regulatory body is part of the government ministry: Dummy variable indicating } \\
\text { whether the regulatory body is constituted as a part of the government ministry or } \\
\text { not. }\end{array}$ & $293(95.7 \%)$ & $13(4.3 \%)$ \\
\hline $\begin{array}{l}\text { Price cap: Dummy variable indicating whether the tariff regulation imposed by the } \\
\text { regulator is a price cap. }\end{array}$ & $283(92.2 \%)$ & $24(7.8 \%)$ \\
\hline $\begin{array}{l}\text { Investment requirements: Dummy variable indicating whether there are or not } \\
\text { investment requirements as part of the concession contract. }\end{array}$ & $235(76.5 \%)$ & $72(23.5 \%)$ \\
\hline $\begin{array}{l}\text { Private financing: Dummy variable indicating whether the project is funded } \\
\text { entirely through private funds (without any financial investment of the state, } \\
\text { whether local or national) or not. }\end{array}$ & $160(52.1 \%)$ & $147(47.9 \%)$ \\
\hline $\begin{array}{l}\text { Bidding process: Dummy variable indicating whether there was or not a bidding } \\
\text { process to award the concession. }\end{array}$ & $272(88.6 \%)$ & $35(11.4 \%)$ \\
\hline $\begin{array}{l}\text { Award criteria: Dummy variable classifying award criteria (1 for highest price, } \\
\text { highest canon or lowest subsidy, } 0 \text { for all others) }\end{array}$ & $106(34.5 \%)$ & $201(65.5 \%)$ \\
\hline $\begin{array}{l}\text { Minimum income guarantee: Dummy variable indicating whether there is or not a } \\
\text { government guarantee in terms of minimum income promissory. }\end{array}$ & $63(20.5 \%)$ & $244(79.5 \%)$ \\
\hline $\begin{array}{l}\text { Arbitration process: Dummy variable indicating whether there is or not a formal } \\
\text { set of arbitration processes stated in the contract providing for the settlement of a } \\
\text { dispute between the concession holder and the government, should such a situation } \\
\text { arise. }\end{array}$ & $179(58.3 \%)$ & $128(41.7 \%)$ \\
\hline $\begin{array}{l}\text { Election: Dummy variable indicating whether there were or not national elections } \\
\text { (legislative or presidential) in any given year. Source: Political Database of the } \\
\text { Americas. Georgetown University/Organization of American States. Center for } \\
\text { Latin American Studies. }\end{array}$ & n.r. & n.r. \\
\hline $\begin{array}{l}\text { Political Change: Dummy variable indicating whether there were or not a change } \\
\text { in power following national elections (legislative or presidential) in any given } \\
\text { year. Source: Political Database of the Americas. Georgetown } \\
\text { University/Organization of American States. Center for Latin American Studies. }\end{array}$ & n.r. & n.r. \\
\hline Continuous variables & Mean & S.D. \\
\hline $\begin{array}{l}\text { Duration since award: Indicates the number of years a concession has been in } \\
\text { operation since its award. }\end{array}$ & n.r. & n.r. \\
\hline $\begin{array}{l}\text { Corruption: Index from Political Risk Service, International Country Risk Guide; } \\
\text { annual values from } 1989 \text { to } 1995 \text {, and } 1998 \text { value after that. Range from } 1 \text { to } 6 . \\
\text { Higher value means less corruption. }\end{array}$ & 2.94 & 0.69 \\
\hline $\begin{array}{l}\text { Rule of law: Index from Political Risk Service, International Country Risk Guide; } \\
\text { annual values from } 1989 \text { to } 1995 \text {, and } 1998 \text { value after that. Range from } 1 \text { to } 6 . \\
\text { Higher value means better rule of law. }\end{array}$ & 2.92 & 0.99 \\
\hline $\begin{array}{l}\text { Bureaucratic quality: Index from Political Risk Service, International Country } \\
\text { Risk Guide; annual values from } 1989 \text { to } 1995 \text {, and } 1998 \text { value after that. Range } \\
\text { from } 1 \text { to } 6 \text {. Higher value means better bureaucratic quality. }\end{array}$ & 3.36 & 0.61 \\
\hline $\begin{array}{l}\text { Growth: Yearly growth rate of GDP in real terms. Source: World Bank and Inter- } \\
\text { American Development Bank. }\end{array}$ & n.r. & n.r. \\
\hline $\begin{array}{l}\text { Exchange rate: Annual evolution of the real exchange rate (calculated as (index } \\
\text { rate of year } \mathrm{t} \text { - index rate of year } \mathrm{t}-1 \text { )/index rate of year } \mathrm{t} \text { ). A positive value } \\
\text { indicates depreciation. Source: Inter-American Development Bank. }\end{array}$ & n.r. & n.r. \\
\hline
\end{tabular}

Tables 2 and 3 summarize the incidence of the different types of renegotiations (led by firms, the government or both), crossing countries and years in the first case, countries, sectors and sub-sectors in the second case. 
Table 2: Renegotiations by type of initiator and year

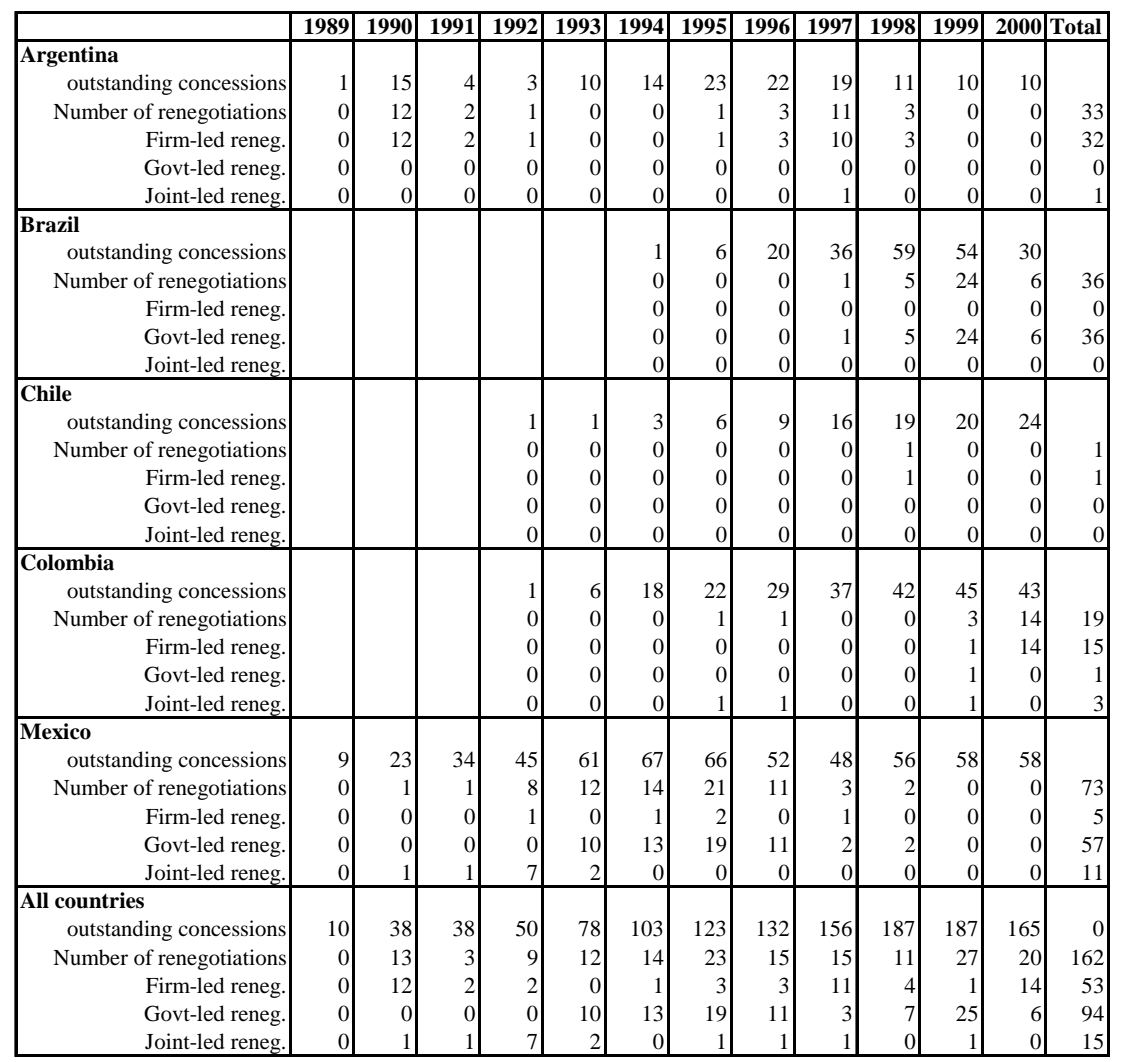


Table 3: Renegotiations by type of initiator and sector

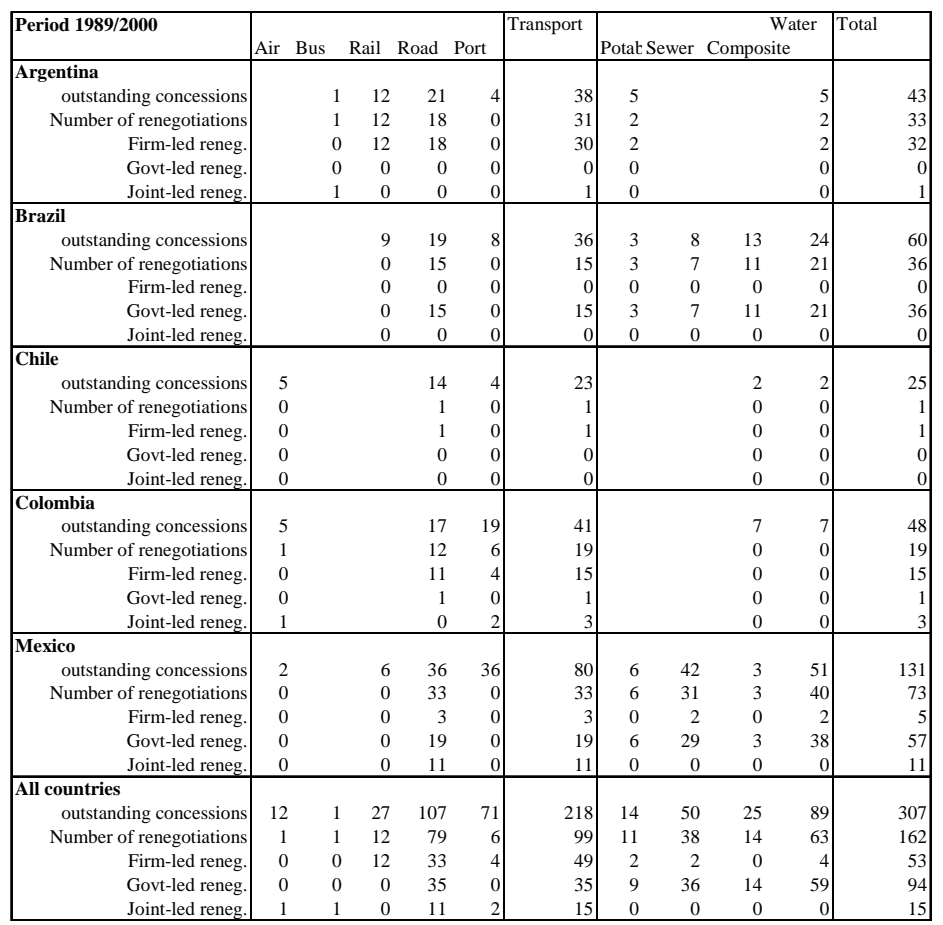

162 out of 307 projects were renegotiated, with 53 firms' calls, 15 joint calls and 94 governments' call. These government-led renegotiations appear to be concentrated in Brazil (36), Mexico (57) and Colombia (1). The Brazilian wave of renegotiation occurred between 1997 and 2000, with a peak in 1999 (24). In Mexico, it was between 1993 and 1998, with more than 10 renegotiations in each year from 1993 to 1996, and a peak of 19 in 1995 (see Table 4 below).

Table 4: Govt-led renegotiations by country, year and sector

\begin{tabular}{|lccccccccc|}
\hline & 1993 & 1994 & 1995 & 1996 & 1997 & 1998 & 1999 & 2000 & Total \\
\hline $\begin{array}{l}\text { Brazil } \\
\text { Colombia }\end{array}$ & & & & & $0 / 1$ & $0 / 5$ & $15 / 9$ & $0 / 6$ & $15 / 21$ \\
Mexico & $5 / 5$ & $8 / 5$ & $3 / 16$ & $1 / 10$ & $2 / 0$ & $0 / 2$ & & & $19 / 38$ \\
\hline
\end{tabular}

(Renegotiations in the transport sector/ Renegotiations in the water sector) 
As for the sector allocation, renegotiated transport projects are exclusively road projects (15 in Brazil, 1 in Colombia and 19 in Mexico). Renegotiated water projects are more evenly distributed: Of the 21 Brazilian cases, 3 were in potable water, 7 in sewer, and 11 in composite projects, while of the 38 Mexican cases, 6 were in potable water, 29 in sewer, and 3 in composite projects.

The most quoted reasons for the renegotiation calls are the need to adjust tariffs or redefine investment, often in the light of demand levels that appeared to be significantly lower than was initially expected. Indeed, highway traffic forecasts have generally been too optimistic, with subsequent traffic shortfall of $60 \%$ in Mexico and $40 \%$ in Colombia. This was probably due to the willingness to make concessions more attractive to investors. The impact of currency devaluation provoking the bankruptcy of the operator has also been a frequent occurrence, especially in Mexico. This led either to a redefinition of the initial contract with more advantageous clauses for the concessionaire, including longer duration, new tariffs and in some cases government subsidies, or to the government taking-over the project (20 cases). Finally, there are also a few cases where the concessionaire was not complying with the terms of the project and the contract was cancelled or suspended $(16 \text { cases })^{20}$.

\subsection{Timing of Renegotiations}

To contrast the relevance of our theoretical approach, we start by analyzing the timing of the different types of renegotiation, in particular with respect to election deadlines. Figure 3 shows the number of governmentand concessionaire-led renegotiations, disaggregating them by looking at how many elections took place during the life of the project. As is apparent, government-led renegotiations tend to be strongly concentrated after the first election (79\% of the total), while concessionaire-led ones are more evenly distributed and take place almost with equal frequency after 0,1 , or 2 elections $^{21}$.

\footnotetext{
${ }^{20}$ See Harris, Hodges, Schur and Shukla (2003).

${ }^{21}$ Note that a representation of sample hazard rates, showing these figures as percentages of outstanding concessions, gives similar results.
} 


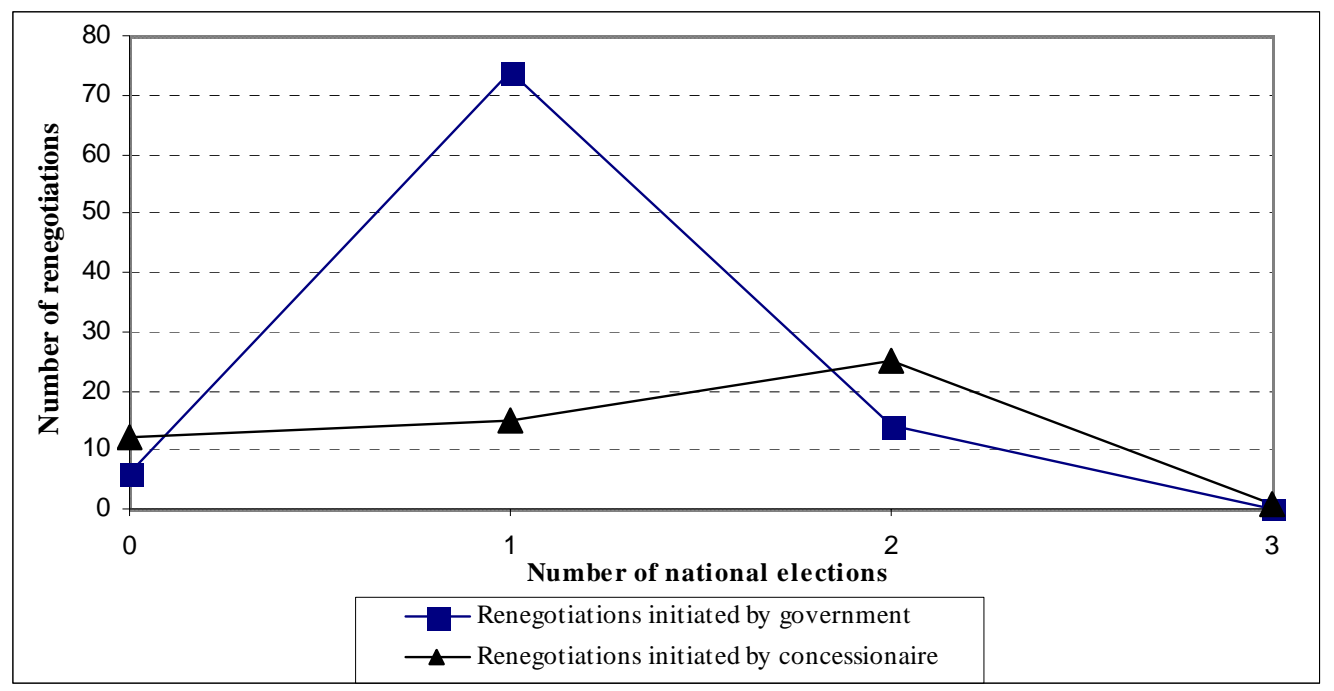

Figure 3: Elections and the timing of renegotiations

We confirm these stylized facts in the probit analysis. Indeed, results not shown here indicate that a lagged dummy for the first election is positive and significant at the $5 \%$ level on the probability of government-led renegotiation, with a marginal effect slightly above $10 \%$, while it is negative and not significant for firm-led renegotiation. Overall, this gives a picture consistent with our model assumption, namely that concessionaire-led renegotiations tend to occur mainly for contractual reasons or in response to adverse unexpected shocks, while government-led renegotiations are generally politically motivated and are likely to follow elections. A more accurate analysis would need to take into account political changes occurring through elections, both at the national and the local level. The specificity of Latin American politics, however, makes it difficult to identify political changes. For example, newly elected governments or parliamentary majorities responding to the same party as their predecessor very often come from a different faction of this party, with very different political agenda, and should thus be considered as representing a political change. A striking example is the assassination of Donald Collosio, the Mexican officially designated presidential candidate of the Institutional Revolutionary Party (PRI), in December 1994, which is thought to have been ordered by members of its own party. Thus, while the PRI remained in power after Mexico's 1995 elections and we would not formally classify this transition as a political change, there is some indication that a different political group actually became dominant at that time. 
This is clearly relevant to renegotiations in Mexico at the initiative of the government in our sample, as 34 of the 57 cases occurred in or after 1995.

Finally, many concessions in our sample, especially in water and some toll road projects, have a local scope, which makes political changes occurring after municipal or regional elections the relevant ones. Indeed, preliminary tests with partial data confirm the pattern of Figure 3.

\subsection{Methodology}

Given the expression for $\pi(x)$, and the comparative statics already discussed in GLS, it is possible to derive from the model a set of predictions for the effect of different variables on the probability of government-led renegotiation. These prediction, together with the details about the empirical proxies that will be used to test them in the following section, are in Table 5 below.

Table 5: Prediction of the model and empirical proxies

\begin{tabular}{|c|c|c|c|}
\hline $\begin{array}{l}\text { Variables of the } \\
\text { theoretical model }\end{array}$ & Variables of the empirical model & Expected effect & $\begin{array}{c}\text { Comparison } \\
\text { with firm-led } \\
\text { renegotiation }\end{array}$ \\
\hline $\begin{array}{l}\text { Probability of } \\
\text { renegotiation }\end{array}$ & $\begin{array}{l}\text { Renegotiation initiated by the government: Dummy variable indicating } \\
\text { whether there was or not a renegotiation of the concession contract at the } \\
\text { initiative of the government. }\end{array}$ & left-hand variable & \\
\hline $\begin{array}{l}\text { The pre-contract } \\
\text { asymmetry of } \\
\text { information } \\
\text { determines the power } \\
\text { of incentives }\end{array}$ & Price cap: Dummy variable taken as a proxy for the power of incentives. & ambiguous & same \\
\hline Sunk cost F & $\begin{array}{l}\text { Investment requirements: Dummy variable indicating whether there are or } \\
\text { not investment requirements as part of the concession contract, investment } \\
\text { being considered to be mainly sunk. }\end{array}$ & ambiguous & reversed \\
\hline Private financing $\mathrm{K}$ & $\begin{array}{l}\text { Private financing: Dummy variable indicating whether the project is } \\
\text { funded entirely through private funds, excluding any public investment. }\end{array}$ & ambiguous & reversed \\
\hline Shocks $\varepsilon$ & $\begin{array}{l}\text { Growth / Exchange rate shocks: internal or external macroeconomic shocks } \\
\text { that impact either cost or demand of the firms. }\end{array}$ & - & same \\
\hline Institutional quality $\theta$ & $\begin{array}{l}\text { Indices of corruption / rule of law / bureaucratic quality: standard } \\
\text { perception indices taken as proxies of institutional quality }\end{array}$ & + & reversed \\
\hline $\begin{array}{l}\text { Elections/political } \\
\text { changes 1-q }\end{array}$ & $\begin{array}{l}\text { Elections: Changes of the political majority are considered to trigger offer } \\
\text { to renegotiate from the new government. } \\
\text { Existence of regulator: Dummy variable indicating whether there was a } \\
\text { regulator or no at the time the contract was signed. The existence of a } \\
\text { regulator might correspond to a lower ability to renegotiate by new } \\
\text { government. }\end{array}$ & + & $\begin{array}{l}\text { same } \\
\text { same }\end{array}$ \\
\hline
\end{tabular}

The important point here is that the effect of any variable having an impact on the probability of renegotiation through the enforcement effort of the government, $\pi(x)$, will have opposite effects, in terms of sign, on the probability of renegotiation at the initiative of the concessionaire versus the 
government $^{22}$. This is in particular the case of the financing variables, $K$ and $F$, and of the institutional quality variables $\theta$, for example corruption. On the other hand, the effects of shocks or of the existence of a regulator, appear to be unchanged.

Tables 7 to 9 present the results from random probit estimations, using as dependent variable the dummy indicating, for each project $i$ in country $n$, whether there is a renegotiation initiated by the government at time $t$, where $t$ varies between 1989 and 2000. Additionally, Table 10 presents robustness checks using as a dependent variable the dummy variable indicating whether there is a renegotiation initiated by the government or by both parties (Tables 7 to 10 are in the Appendix). The model, which is a linearized version of the theoretical equation giving the probability of renegotiation, is the following:

$$
y_{i n t}=1\left[y_{i n t}^{*}=x_{i} \alpha_{1}+\alpha_{3} z_{i n t}+E_{n t} \alpha_{3}+e_{i n t}<0\right],
$$

where $1[$.$] is the indicator function taking value 1$ whenever the statement in brackets is true, and 0 otherwise; $y_{\text {int }}$ is the binary variable indicating whether concession $i$, in country $n$, at time $t$, was renegotiated or not at the initiative of the government; $x_{i}$ is a vector of time invariant characteristics of the concession contracts; $z_{i n t}$ is the number of years, since the award of concession $i$, in country $n ; E_{n t}$ is a vector of environmental characteristics (macroeconomic indicators, elections and institutional indices); $e_{i n t}$ is the error term; and $\alpha_{1}, \alpha_{2}$, and $\alpha_{3}$ are the vectors of parameters corresponding to $x_{i}, z_{i n t}$ and $E_{n t}$ respectively.

Table 7 shows the basic specifications. Table 8 presents instrumental variable estimations, where we make use of a two-stage procedure to address the potential endogeneity of contract clauses $^{23}$. Table 9 introduces some additional variables and interactions related to institutional and political aspects.

We instrument the variables found to be endogenous applying the simple Rivers-Vuong (1988) test. The instruments are sectors, corruption, bureaucracy quality, rule of law, and existence of regulatory body, which are exogenous in the sense that they are not determined by the risk of potential

\footnotetext{
${ }^{22}$ The absolute magnitude of the effects, however, may vary.

${ }^{23}$ Although such an estimation is in principle biased when the endogenous variable is binary (see Wooldridge, 2002), support for it can be found in Angrist (1991) who states that the bias is negligible. The second stage standard errors are computed using a bootstrapping procedure. See a more detailed discussion in GLS.
} 
renegotiations. In particular, think of the institutional variables as affecting renegotiation of individual concessions only indirectly through their effect on the broader business and legal environment (the variable $\theta$ in the model) and thus on the choice of contract clauses. Even if a case is made for any of these variable to enter the equation explaining renegotiation, note that identification would still ensured by the non-linearity of the model. Table 6 summarizes the results of the test, which standard errors are bootstrapped to account of the potential correlation of errors over time:

Table 6: Exogeneity tests

\begin{tabular}{|l|c|}
\hline \multicolumn{1}{|c|}{ Variable } & Rivers-Vuong test: Exogeneity \\
\hline Price cap & Rejected at $1 \%$ \\
\hline Investment requirements & Accepted \\
\hline Private financing & Rejected at $10 \%$ \\
\hline Award criteria & Accepted \\
\hline Arbitration Process & Accepted \\
\hline Minimum income guarantee & Rejected at $5 \%$ \\
\hline Bidding process & Accepted \\
\hline
\end{tabular}

Note that there are good intuitive reasons for the results of the exogeneity test. Indeed, we would expect contractual aspects that are routinely predetermined to be exogenous as they are unlikely to be altered by subsequent strategic interactions between the government and potential concessionaires. This is obviously the case of the award criteria, the inclusion of an arbitration process, which generally depends on the existing legal framework, and the fact that the concession is awarded through a bid (used in $89 \%$ of the cases). On the other hand, it is sometimes the case that concessions are granted on the basis of materials that focus on technical criteria and investment requirements but are drafted in the absence of sector laws and regulatory expertise and only weakly delineate what future regulation and tariff adjustment rules would be (Guasch, 2004). Similarly, as argued in GLS, both the structure of financing and the inclusion of guarantee clauses are likely to result from strategic considerations concerning the attractiveness of a concession to private operators and the degree of risk involved. 
Before going to the results, we discuss briefly the first stage estimations for the three variables deemed endogenous. The choice of regulation appears to hinge mostly on the quality of institutions. Price cap regulation is less likely when the bureaucracy is more efficient, capturing perhaps the enhanced ability of bureaucrats to manage informationally demanding schemes like rate of return regulation. On the other hand, more generic measures like corruption and rule of law appear to have the opposite effect. One possibility is that price caps are less attractive for government in environments characterized by higher risk of bribery and weak enforcement. However, overall the bureaucratic efficiency effect seems to dominate.

As for exclusive private financing, it dominates in the transport sector (private operators may be less willing to assume alone the huge and ex ante uncertain modernization costs of obsolete water delivery systems). The existence of a regulator ex ante also increases the probability of some government participation in financing, maybe because it represents the implicit guarantee of better administrative control over the project. A better bureaucracy makes private financing more likely, probably capturing the fact that better bureaucrats find it easier to convince private investors of the convenience to invest. As for corruption, it has the opposite effect, which can be related to the effect commonly observed in FDI studies, showing that private investors prefer direct involvement in situation of weak governance for risk sharing purposes (Straub, 2005).

Finally, minimum income guarantee clauses are especially prevalent in transport projects, probably due to the high uncertainty surrounding future demand and as a way to make them attractive to private investors (see Engel et al. 2003 and INCO, 2004). Such clauses also appear to be more likely when a regulator is present.

\subsection{Results}

We present the main results for the determinants of government-led renegotiation below, making special mention of how they relate to similar estimations in GLS. We discuss first the core variables.

- The existence of a regulatory body is again negative and significant most of the time. Its economic impact, however, appears to be smaller (about half) of what it is for firm-led renegotiations. Also, we again observe that it loses statistical significance when instrumental estimations are performed, which we interpret as being linked to the fact that this variable is used in the first 
stage estimation and that it is effective through better contract clauses.

- The price cap variable, which is one of the most important result in the context of firm-led renegotiations, does not yield consistent results in Table 7. It does however when instrumented in Table 8, being again positive and strongly significant. Thus, the risk effect of price cap regulation (renegotiation to relax an excessively stringent cap) appears to dominate a potential rent-shifting motive (government renegotiation to limit excessive rents due to a loose cap).

- Duration since award is positive and very significant, and its marginal effect is slightly stronger than on firm-led renegotiations (between 0.8 and $1.5 \%$ increase in probability for each additional year, against 0.3 to $0.6 \%$ previously).

- The existence of investment requirements is negative and generally not significant in Table 7. Note that here exogeneity is accepted by the test although it was rejected in the case of firm-led renegotiations. If instrumented, the investment variable changes sign and becomes positive and strongly significant, which is exactly the contrary of the findings in the case of firm-led renegotiations ${ }^{24}$.

- Exclusive private financing has a reducing effect on the probability of renegotiations (the reverse of the pattern observed for firm-led renegotiations), and appears to be strongly significant both in Table 7 and when instrumented in Table 8. Its marginal effect is also much stronger here and is up to $5 \%$.

- The quality of bureaucracy is still negative and significant throughout, and its economic impact is now slightly above 1\%. However, the corruption variable, whether introduced alone or together with the quality of bureaucracy index, is positive and significant in Table 7 , meaning that a less corrupt environment is conducive to more renegotiation. This is consistent with our theoretical framework that implies a reverse effect for that variable. Intuitively, the quality of the bureaucracy dimension may be related to a contract-improving effect similar to the one linked to the existence of a regulator, while corruption would capture the standard effect through the $\pi(x)$ function.

- The lagged election variable is still positive, implying more renegotiations after national elections. Its significance varies between 0.2 and $0.6 \%$ depending on what other variables are included in the specification.

\footnotetext{
${ }^{24}$ Results, not shown here to save space, are available upon request from the authors.
} 
- The economic cycle has again an impact on the probability of renegotiations, with lagged growth shocks implying more renegotiations. They appear however to matter slightly less (this makes sense if a significant fraction of them are rather linked to the political cycle) and in a different way than for firm-led renegotiations: The marginal effect is lower (around +0.2 and $+0.1 \%$ after one and two years respectively for each one-point decrease in the growth rate), and the effect is stronger with a one year lag and decreases after that. A similar pattern is observed for exchange rate shocks ${ }^{25}$.

Additional variables introduced in Table 7 include:

- The existence of an arbitration process, which we had previously related to the cost of renegotiation $\delta$, is here negative and significant (column 3). Exogeneity is accepted for this variable.

- Minimum income guarantee is consistently positive and strongly significant, and this carries over when it is instrumented (Table 8). Its marginal effect is quite strong (around 5\%), which indicates the inappropriateness of such clauses. In the case of Colombia's road program, the cumulated amount of guarantees due by the State to concessionaires as of 2004 amounts approximately to the equivalent of US\$100 million, threatening to weight heavily on future fiscal results. For this reason, least present value of revenue auctions have been introduced for new concessions awards, as a way to substitute for this type of guarantees (INCO, 2004).

- The existence of a bidding process previous to the award of the concession is positive but not significant (column 4).

- A dummy variable classifying award criteria (1 for highest price, highest canon or lowest subsidy, hence monetary transfer considerations not prone to subsequent interpretational subjectivity, 0 for others), shows up negative and significant (table 7, column 7). Note that exogeneity is accepted for that variable. Looking in more details at specific award criteria, it appears that three of them are significant: lowest tariff and best plan (where the criterion is based on evaluating business plans that include service parameters, investment commitment and the record of the concessionaire) have a significant and negative impact on the probability of renegotiation, both with marginal effects near 1\%, while shortest duration (where the concession is awarded to the bidder seeking the shortest duration of exclusive operating rights) is significantly positive and its marginal effect is around $13 \%{ }^{26}$.

\footnotetext{
${ }^{25}$ Results are not shown here to save space.

${ }^{26}$ These results call for further inquiry, but are left for future research. See Engel, Fischer
} 
Table 11 summarizes the results by showing the sign of the main determinants found to have an effect on both types of renegotiations. In particular, it highlights (shaded rows) that the sign of the investment, private financing and corruption variables are indeed reversed, which provides supports for the theoretical model presented in the first part of this paper.

Table 11: Comparative summary of the results

\begin{tabular}{|l|c|c|}
\hline & Government-led renegotiation & Firm-led renegotiation \\
\hline Existence of a regulator & Negative & Negative \\
\hline Price cap regulation & Positive & Positive \\
\hline Duration & Positive & Positive \\
\hline Investment requirements & Positive & Negative \\
\hline Exclusive private financing & Negative & Positive \\
\hline Quality of bureaucracy & Negative & Negative \\
\hline Corruption & Positive & Negative \\
\hline Elections (lagged) & Positive & Positive \\
\hline Growth (lagged) & Negative & Negative \\
\hline Minimum income guarantee & Positive & Positive \\
\hline
\end{tabular}

Moreover, several results with strong policy implications are unchanged, namely the fragility of price cap regulation, the fact that having a regulator in place when signing a concession contract and setting up a regulatory framework reduces the frequency of future renegotiation calls, and the inadequacy of minimum income guarantee clauses. The next section digs further into the institutional and regulatory environment of successful concessions.

\subsection{Institutional and Political Aspects}

Table 9 introduces additional variables and interactions, meant to explore further the impact of institutional and political aspects.

In column 1 and 2, we introduce the fact that the regulator is part of the government ministry or not. This variable, which can be interpreted as a proxy for the autonomy of the regulatory body, has a strong positive and significant impact on the probability of renegotiations (marginal effect

and Galetovic (2001 and 2003) for a discussion of award criteria, including their proposal of a least present value of revenue auction. 
around $1 \%)^{27}$. Therefore, it appears that a regulator enjoying some degree of independence from the politicians in charge is much more effective in limiting renegotiation. Interestingly, the inclusion of this variable does not affect the significance and sign of the "existence of a regulatory body" variable. Note finally that it has exactly the opposite effect when the dependent variable is concessionaire-led renegotiations. This result can be tentatively related to the one on corruption. We investigate further on this possibility below.

In column 2 , we substitute the lagged election variable by a more focused variable, i.e. a dummy indicating effective political changes following these elections. This variable is defined by imputing as changes cases in which there was a shift in the dominant party majority in Congress, or a new president coming from a different party than his or her predecessor (see discussion above). This specification improves a little on the election variable. Considering other specifications not included here, the results are however comparable. As mentioned before, the scope of many concessions (especially in water) are limited to local or regional political districts, so we would need to construct similar reliable variables (elections and effective changes of majority) at the level of the relevant local elections to be able to test the effect of political turnover more precisely.

In column 3, we interact the dummy variable for the existence of a regulator with the corruption index. The interaction is positive and significant at the $1 \%$ level, while the dummy for the existence of a regulator remains negative and significant. Considering that a higher value of the corruption index corresponds to a less corrupt environment, this can be interpreted by saying that the stronger corruption, the more important the effect of having a regulator in place to limit the incidence of renegotiations. This results tends to indicate that the impact of a regulatory body is especially important in weak governance environments.

In column 4, we interact the quality of the bureaucracy index with the election variable, to see if the effect of political cycles is affected by the general perceived quality of institutions. The interaction comes out negative and significant, and so do the two interacted variables. This shows that the better the bureaucracy, the milder the post-election effect. In column

\footnotetext{
${ }^{27}$ Arguably, not being part of a ministry does not guarantee operative autonomy, as other indirect form of political interference may exist. See Cubbin and Stern (2005) and Wallsten (2001), for cross-country evidence that improved regulatory independence and quality have a positive impact on performance and efficiency in the electricity and telecommunication sectors respectively.
} 
5 a similar result is obtained by interacting the election variable with the corruption index (negative and significant sign), and in column 6, we combine the interaction between the existence of a regulator and the corruption index with that of the election variable with the corruption index, and still obtain the same results for both.

Overall the results in Table 9 give additional evidence of the fact that strong regulatory mechanisms are specially important when the institutional quality is low. In this context, experienced and independent regulators are likely to act as barriers against political opportunism.

\subsection{Robustness Checks}

In our model, government-led renegotiations are both Pareto improving and rent shifting ones. Empirically, our sample contains a small number of renegotiations that are considered to be the result of a joint call. As discussed in GLS, this may both reflect the fact that the renegotiation was desired by both parties or that there was not a clear case to attribute the call, as with some Mexican road projects. In any case, it can be argued that joint calls are close in nature to Pareto improving government calls, so Table 10 (see Appendix) presents robustness checks using as a dependent variable the dummy variable indicating whether there is a renegotiation initiated by the government or by both parties. Overall, the main results are unchanged. Some noticeable differences include:

- The marginal effect of private financing is stronger and up to $10 \%$.

- The significance of the lagged election variable is reinforced. In this case, it is significant at the 1 or $5 \%$ level in all cases and its marginal effect is around $2 \%$.

- The existence of a bidding process becomes weakly significant (positive and significant at 10\% level with a marginal effect near 3\%).

\section{Conclusion and Policy Implications}

We have built a model of renegotiation of concession contracts in which the principal, the government, initiates both Pareto improving and rent-shifting renegotiations. Moreover, we have tested its predictions with a sample of 307 Latin American transport and water concessions in the 1990s. 
Overall, the analysis of government-led renegotiations confirms some of the main insight that Guasch, Laffont and Straub (2003) presented with respect to firm-led renegotiation. Concessions' fragility is due to a mix of flaws in contract design, inadequate regulatory frameworks and deficient institutional environments, and the impact of macroeconomic shocks. Key results are again the importance of having a regulator in place when awarding concessions and the sensitivity of price cap regulated concessions to shocks.

There are, however, important differences with firm-led renegotiations. Most importantly, the financing variables (those affecting the status quo payoffs of the renegotiating parties, and especially the exclusivity of private financing) tend to come out with reversed signs, which is what we should expect from the way they affect the firm and the government in the bargaining process. Moreover, a proxy for the autonomy of the regulator also comes out with reversed sign, as does the corruption variable.

The main additional policy insights come from better and more precise evidence of the link between the regulatory framework and the institutional and political environment. Indeed, it appears that having efficient and independent regulatory authorities in place when awarding concessions is especially important because it helps limit the damaging effects of corruption, weakness in the rule of law and the bureaucratic framework, as well as the potential strategic behavior of the government following changes in power. 


\section{References}

Angrist, J. (1991), "Instrumental Variables Estimation of Average Treatment Effects in Econometrics and Epidemiology", National Bureau of Economic Research Technical Working Paper Number 115.

Aubert, C. and J.J. Laffont (2002), "Political Renegotiation of Regulatory Contracts", mimeo, Toulouse.

Besley and Coate (2003), "Elected versus Appointed Regulators: Theory and Evidence", Journal of the European Economic Association, 1(5), 11761206. 2003.

Cubbin, J. and J. Stern (2005), "Regulatory Effectiveness : The Impact of Regulation and Regulatory Governance Arrangements on Electricity Industry Outcomes", World Bank Policy Research Working Paper 3536, Washington D.C.

Engel, E., R. Fischer and A. Galetovic (2003), "Privatizing Highways in Latin America: Fixing What Went Wrong", Economia, 4(1), 129-164.

Engel, E., R. Fischer and A. Galetovic (2001), "Least Present Value of Revenue Auctions and Highway Franchising", Journal of Political Economy, 109(5), 993-1020.

Estache A., L. Guasch and L. Trujillo, (2003), "Price Caps, Efficiency Payoffs, and Infrastructure Contract Renegotiation in Latin America", World Bank Policy Research Working Paper 3129, Washington D.C.

Guasch, L. (2004), Granting and Renegotiating Concessions. Doing it Right, World Bank Institute Development Studies, Washington D.C.

Guasch, L. and P. Spiller, (1999), Managing the Regulatory Process: Design, Concepts, Issues and the Latin American and Caribbean Story, The World Bank, Washington D.C.

Guasch, Laffont and Straub (2003), "Renegotiation of Concession Contracts in Latin America", mimeo, University of Edinburgh, and World Bank Policy Research Working Paper 3011.

Harris, C. (2003) "Private Participation in Infrastructure in Developing Countries. Trends, Impacts, and Policy Lessons", World Bank Working Paper No.5, Washington D.C.

Harris C., J. Hodges, M. Schur and P. Shukla (2003), "Infrastructure Projects: A Review of Cancelled Projects", Public Policy for the Private Sector, Note 252, World Bank.

INCO (2004), "Alternativas de Reestructuración para las Concesiones de Carreteras y Ferrocarriles", propuesta de documento CONPES preparado 
por la oficina de evaluación, Instituto Nacional de Concesiones, Bogotá.

Laffont, J.J. and D. Martimort (2002), The Theory of Incentives I, The Principal-Agent Model, Princeton University Press, Princeton.

Laffont, J.J. and J. Tirole (1993), A Theory of Incentives in Procurement and Regulation, Third Printing. Cambridge, United States: MIT Press.

Rivers D. and Q. Vuong (1988), "Limited Information Estimators and Exogeneity Tests for Simultaneous Probit Models", Journal of Econometrics, 39, 347-366.

Rose-Ackerman, S. (1999), Corruption and Government: Causes, Consequences, and Reform, Cambridge: Cambridge University Press.

Straub, S. (2005), "Opportunism, Corruption, and the Multinational Firm's Mode of Entry", mimeo, University of Edinburgh.

Wallsten, S. (2001), "An Econometric Analysis of Telecom Competition, Privatization, and Regulation in Africa and Latin America", The Journal of Industrial Economics, 49(1), 1-19.

Wooldridge, J.M. (2002), Econometric Analysis of Cross Section and Panel Data, Cambridge, MA: MIT Press. 


\section{Appendix}

In the case with limited liability but without political turnover, this condition, spelled out for the general model in footnote 13 of Guasch, Laffont and Straub (2003), is given by:

$$
\begin{aligned}
& \underline{U}_{1} \geq \\
& \pi(x)\left[\bar{U}_{1}+\Phi\left(\bar{e}^{L}\right)\right]+(1-\pi(x))(1-P)\left[\bar{U}^{E}+\Phi\left(\bar{e}^{L}\right)\right]+(1-\pi(x)) P[-A] .
\end{aligned}
$$

The structure of rents giving rise to this condition is shown in the figure below:

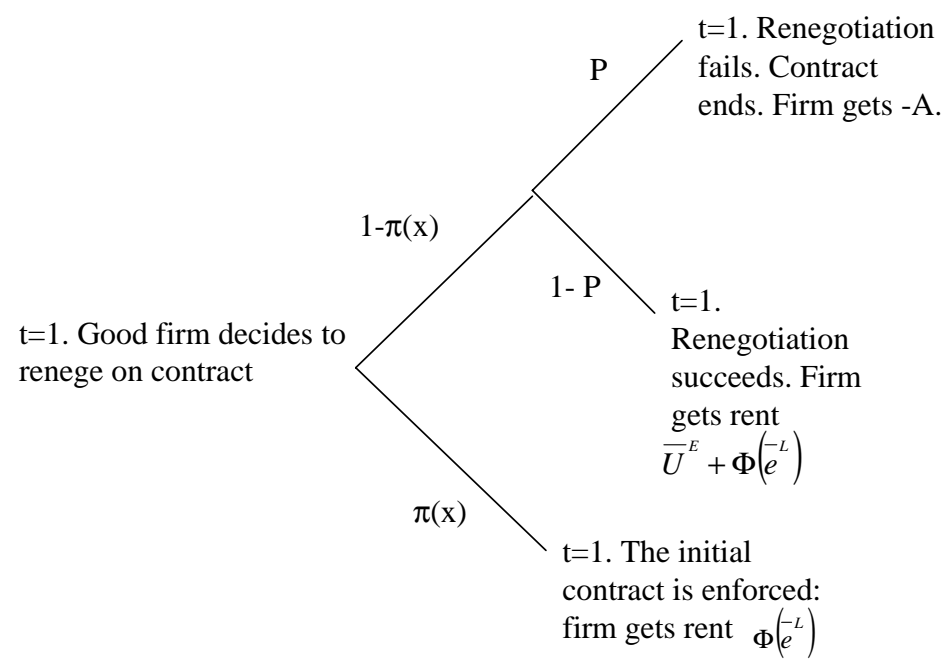

Rent accruing to good firm cheating (1 period)

In the present case, we must consider the additional fact that at $t=2$ there is a probability $1-q$ that $\bar{q}^{L}$ be increased to the first best level $\bar{q}^{*}$, giving rise to a higher rent for a cheating firm. Note that we do not explicitly distinguish the case of outright expropriation (probability $(1-q) \mu$ ), as the production level and thus the good firm's rent remain the same. The next figure shows this modified rent profile: 


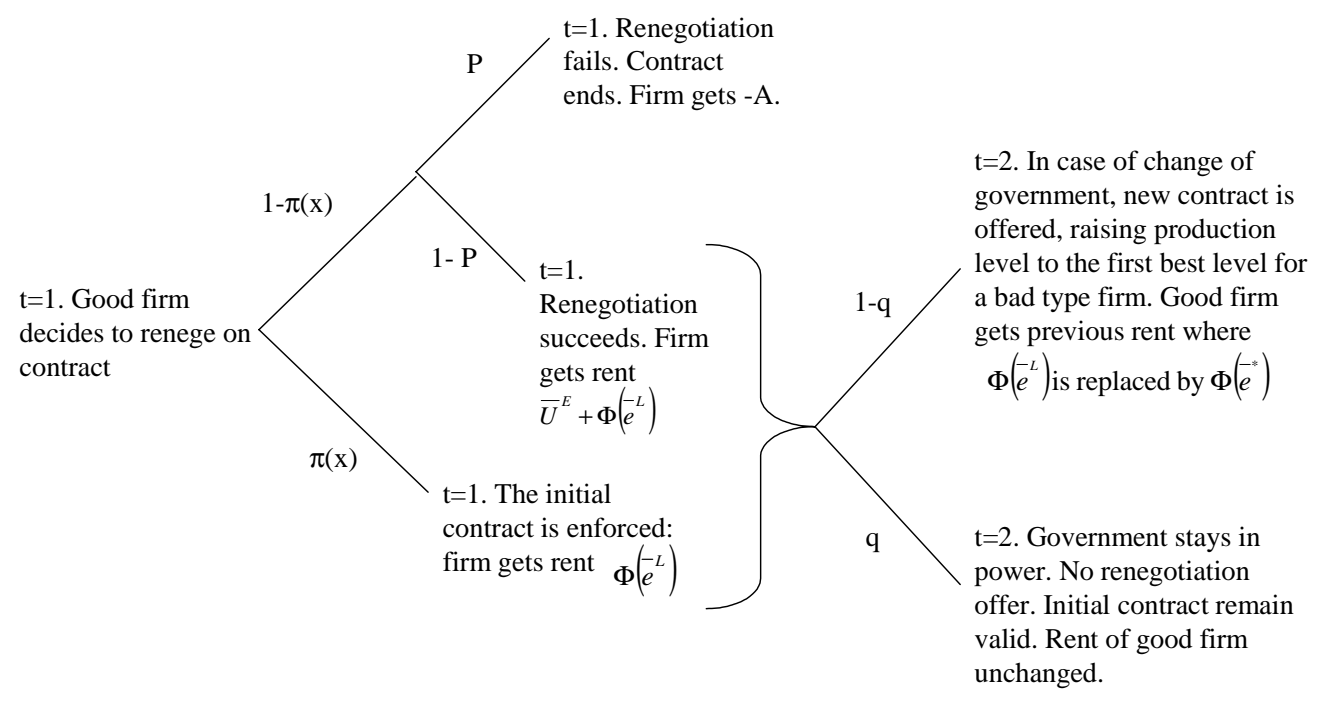

Rent accruing to good firm cheating ( 2 periods)

In this new context, a good firm mimicing a bad one would get (note that $\bar{U}_{1}=0$ here):

$\cdot \pi(x)\left[\Phi\left(\bar{e}^{L}\right)\right]+(1-\pi(x))(1-P)\left[\bar{U}^{E}+\Phi\left(\bar{e}^{*}\right)\right]+(1-\pi(x)) P[-A]$ in period 1 , as in the static model,

$\cdot \pi(x)\left[\Phi\left(\bar{e}^{L}\right)\right]+(1-\pi(x))(1-P)\left[\bar{U}^{E}+\Phi\left(\bar{e}^{*}\right)\right]$ in period 2, with probability $q$,

$\cdot \pi(x)\left[\Phi\left(\bar{e}^{*}\right)\right]+(1-\pi(x))(1-P)\left[\bar{U}^{E}+\Phi\left(\bar{e}^{*}\right)\right]$ in period 2, with probability $1-q$.

Given this, the constraint ensuring truthful behavior from the good type at $t=1$, can now be written

$$
\begin{aligned}
& 2 \underline{U}_{1} \geq \\
& \pi(x)\left[(1+q) \Phi\left(\bar{e}^{L}\right)+(1-q) \Phi\left(\bar{e}^{*}\right)\right]+2(1-\pi(x))(1-P)\left[\bar{U}^{E}+\Phi\left(\bar{e}^{*}\right)\right] \\
& +(1-\pi(x)) P[-A] .
\end{aligned}
$$

Setting $q=0$ gives the constraint in the text. 
Table 7: Random effect probit panel Basic estimations

\begin{tabular}{|c|c|c|c|c|c|c|c|}
\hline & $(1)$ & (2) & (3) & (4) & (5) & (6) & (7) \\
\hline Dependent variable & $\begin{array}{c}\text { Reneg. } \\
\text { initiated by } \\
\text { Govt }\end{array}$ & $\begin{array}{c}\text { Reneg. } \\
\text { initiated by } \\
\text { Govt }\end{array}$ & $\begin{array}{c}\text { Reneg. } \\
\text { initiated by } \\
\text { Govt }\end{array}$ & $\begin{array}{c}\text { Reneg. } \\
\text { Initiated by } \\
\text { Govt }\end{array}$ & $\begin{array}{c}\text { Reneg. } \\
\text { Initiated by } \\
\text { Govt }\end{array}$ & $\begin{array}{c}\text { Reneg. } \\
\text { Initiated by } \\
\text { Govt }\end{array}$ & $\begin{array}{c}\text { Reneg. } \\
\text { Initiated by } \\
\text { Govt }\end{array}$ \\
\hline $\begin{array}{l}\text { Existence of regulatory } \\
\text { body }\end{array}$ & $\begin{array}{l}-0.15 \\
(0.19)\end{array}$ & $\begin{array}{l}-1.01^{*} \\
(0.29)\end{array}$ & $\begin{array}{l}-1.91^{*} \\
(0.47)\end{array}$ & $\begin{array}{l}-0.94^{*} \\
(0.29)\end{array}$ & $\begin{array}{c}0.32 \\
(0.39)\end{array}$ & $\begin{array}{l}-1.44^{*} \\
(0.35)\end{array}$ & $\begin{array}{l}-1.19^{*} \\
(0.32)\end{array}$ \\
\hline Price cap & & $\begin{array}{c}0.19 \\
(0.37)\end{array}$ & $\begin{array}{c}-1.53^{* *} \\
(0.61)\end{array}$ & $\begin{array}{l}-0.08 \\
(0.44)\end{array}$ & $\begin{array}{l}-0.43 \\
(0.43)\end{array}$ & $\begin{array}{l}-0.73 \\
(0.48)\end{array}$ & $\begin{array}{c}0.34 \\
(0.37)\end{array}$ \\
\hline Duration since award & $\begin{array}{l}0.14^{*} \\
(0.04)\end{array}$ & $\begin{array}{l}0.31^{*} \\
(0.05)\end{array}$ & $\begin{array}{l}0.32 * \\
(0.06)\end{array}$ & $\begin{array}{l}0.32 * \\
(0.05)\end{array}$ & $\begin{array}{l}0.37^{*} \\
(0.06)\end{array}$ & $\begin{array}{l}0.30 * \\
(0.05)\end{array}$ & $\begin{array}{l}0.29 * \\
(0.05)\end{array}$ \\
\hline $\begin{array}{l}\text { Investment } \\
\text { requirements }\end{array}$ & & $\begin{array}{c}-0.38^{* * *} \\
(0.20)\end{array}$ & $\begin{array}{l}-0.36 \\
(0.23)\end{array}$ & $\begin{array}{l}-0.33 \\
(0.20)\end{array}$ & $\begin{array}{c}-0.52^{* *} \\
(0.21)\end{array}$ & $\begin{array}{l}-0.60^{*} \\
(0.23)\end{array}$ & $\begin{array}{c}-0.47^{* *} \\
(0.22)\end{array}$ \\
\hline Private financing & & $\begin{array}{l}-1.23^{*} \\
(0.21)\end{array}$ & $\begin{array}{l}-0.70^{*} \\
(0.26)\end{array}$ & $\begin{array}{l}-1.14^{*} \\
(0.22)\end{array}$ & $\begin{array}{l}-1.03^{*} \\
(0.21)\end{array}$ & $\begin{array}{l}-1.19^{*} \\
(0.22)\end{array}$ & $\begin{array}{l}-1.20^{*} \\
(0.22)\end{array}$ \\
\hline Bureaucratic quality & $\begin{array}{l}-0.51^{*} \\
(0.11)\end{array}$ & $\begin{array}{l}-0.52^{*} \\
(0.14)\end{array}$ & $\begin{array}{l}-0.56^{*} \\
(0.17)\end{array}$ & $\begin{array}{l}-0.54^{*} \\
(0.14)\end{array}$ & $\begin{array}{l}-0.75^{*} \\
(0.17)\end{array}$ & $\begin{array}{l}-0.58^{*} \\
(0.16)\end{array}$ & $\begin{array}{l}-0.50^{*} \\
(0.15)\end{array}$ \\
\hline Arbitration process & & & $\begin{array}{l}-2.99^{*} \\
(0.61)\end{array}$ & & & & \\
\hline Bidding process & & & & $\begin{array}{c}0.51 \\
(0.43)\end{array}$ & & & \\
\hline Corruption & & & & & $\begin{array}{l}0.92 * \\
(0.22)\end{array}$ & & \\
\hline $\begin{array}{l}\text { Minimum income } \\
\text { guarantee }\end{array}$ & & & & & & $\begin{array}{l}1.80^{*} \\
(0.43)\end{array}$ & \\
\hline Award criteria & & & & & & & $\begin{array}{l}-1.13^{*} \\
(0.42)\end{array}$ \\
\hline Election-1 & $\begin{array}{l}0.48^{*} \\
(0.12)\end{array}$ & $\begin{array}{c}0.22 \\
(0.16)\end{array}$ & $\begin{array}{l}0.46^{* *} \\
(0.18)\end{array}$ & $\begin{array}{c}0.21 \\
(0.16)\end{array}$ & $\begin{array}{c}0.23 \\
(0.17)\end{array}$ & $\begin{array}{c}0.31^{* * * *} \\
(0.18)\end{array}$ & $\begin{array}{c}0.27 \\
(0.17)\end{array}$ \\
\hline GDP growth -1 & $\begin{array}{l}-0.06^{*} \\
(0.02)\end{array}$ & $\begin{array}{l}-0.07^{*} \\
(0.02)\end{array}$ & $\begin{array}{l}-0.14^{*} \\
(0.03)\end{array}$ & $\begin{array}{l}-0.07^{*} \\
(0.02)\end{array}$ & $\begin{array}{l}-0.11^{*} \\
(0.02)\end{array}$ & $\begin{array}{l}-0.10^{*} \\
(0.02)\end{array}$ & $\begin{array}{l}-0.08^{*} \\
(0.02)\end{array}$ \\
\hline GDP growth -2 & $\begin{array}{l}-0.03 \\
(0.03)\end{array}$ & $\begin{array}{c}-0.06 * * * \\
(0.03)\end{array}$ & $\begin{array}{c}-0.09^{* *} \\
(0.03)\end{array}$ & $\begin{array}{c}-0.06 * * * \\
(0.03)\end{array}$ & $\begin{array}{c}-0.06^{* *} \\
(0.03)\end{array}$ & $\begin{array}{l}-0.09^{*} \\
(0.03)\end{array}$ & $\begin{array}{c}-0.07^{* *} \\
(0.03)\end{array}$ \\
\hline $\begin{array}{l}\text { Transport sector } \\
\text { dummy }\end{array}$ & $\begin{array}{c}-0.95 * * * \\
(0.19)\end{array}$ & $\begin{array}{l}-0.24 \\
(0.30)\end{array}$ & $\begin{array}{l}1.25^{* *} \\
(0.50)\end{array}$ & $\begin{array}{l}-0.30 \\
(0.30)\end{array}$ & $\begin{array}{l}-1.34^{*} \\
(0.38)\end{array}$ & $\begin{array}{l}-1.22 * \\
(0.45)\end{array}$ & $\begin{array}{c}0.18 \\
(0.35)\end{array}$ \\
\hline Number of obs. & 1267 & 1132 & 1100 & 1132 & 1132 & 1127 & 1132 \\
\hline Log Likelihood & -267.08 & -173.70 & -151.72 & -172.94 & -163.95 & -160.58 & -168.33 \\
\hline
\end{tabular}

\begin{tabular}{|c|c|c|c|c|c|c|c|}
\hline $\mathrm{y}=\operatorname{Pr}($ renegotiation=1) & 0.036 & 0.009 & 0.0004 & 0.009 & 0.004 & 0.002 & 0.005 \\
\hline $\begin{array}{l}\text { Existence of regulatory } \\
\text { body }\end{array}$ & -0.012 & -0.041 & -0.016 & -0.035 & 0.004 & -0.21 & -0.32 \\
\hline Price cap & & 0.004 & -0.022 & -0.002 & -0.009 & -0.009 & 0.003 \\
\hline Duration since award & 0.011 & 0.008 & 0.0004 & 0.008 & 0.005 & 0.001 & 0.004 \\
\hline $\begin{array}{l}\text { Investment } \\
\text { requirements }\end{array}$ & & -0.012 & -0.001 & -0.010 & -0.011 & -0.006 & -0.009 \\
\hline Private financing & & -0.055 & -0.002 & -0.047 & -0.024 & -0.013 & -0.032 \\
\hline Bureaucratic quality & -0.041 & -0.013 & -0.001 & -0.013 & -0.010 & -0.003 & -0.007 \\
\hline Arbitration process & & & -0.071 & & & & \\
\hline Bidding process & & & & 0.008 & & & \\
\hline Corruption & & & & & 0.012 & & \\
\hline $\begin{array}{l}\text { Minimum income } \\
\text { guarantee }\end{array}$ & & & & & & 0.048 & \\
\hline Award criteria & & & & & & & -0.013 \\
\hline Election-1 & 0.045 & 0.006 & 0.001 & 0.005 & 0.003 & 0.002 & 0.004 \\
\hline GDP growth -1 & -0.005 & -0.002 & -0.0002 & -0.002 & -0.001 & -0.001 & -0.001 \\
\hline GDP growth -2 & -0.002 & -0.001 & -0.0002 & -0.001 & -0.001 & -0.0004 & -0.001 \\
\hline $\begin{array}{l}\text { Transport sector } \\
\text { dummy }\end{array}$ & -0.119 & -0.007 & 0.001 & -0.009 & -0.055 & -0.021 & 0.002 \\
\hline
\end{tabular}

(a) For dummy variables, dy/dx is for discrete change from 0 to 1. For continuous variables, it corresponds to an increase by 1 unit.
Standard errors in parenthesis. Coefficients significant at the $1 \%\left({ }^{*}\right), 5 \%\left({ }^{* *}\right)$ and $10 \%\left({ }^{* * *}\right)$ level. 
Table 8: Random effect probit panel

Instrumental variable estimations

\begin{tabular}{|c|c|c|c|c|}
\hline & (1) & $(2)$ & (3) & (5) \\
\hline Dependent variable & $\begin{array}{l}\text { Reneg. } \\
\text { Initiated by } \\
\text { Govt }\end{array}$ & $\begin{array}{l}\text { Reneg. } \\
\text { Initiated by } \\
\text { Govt }\end{array}$ & $\begin{array}{c}\text { Reneg. } \\
\text { Initiated by } \\
\text { Govt }\end{array}$ & $\begin{array}{c}\text { Reneg. } \\
\text { Initiated by } \\
\text { Govt }\end{array}$ \\
\hline Existence of regulatory body & $\begin{array}{c}0.29 \\
(0.43)\end{array}$ & $\begin{array}{l}-1.01^{*} \\
(0.29)\end{array}$ & $\begin{array}{c}0.48 \\
(0.43) \\
\end{array}$ & $\begin{array}{l}-2.79 * \\
(1.60)\end{array}$ \\
\hline Price cap & & $\begin{array}{c}0.17 \\
(1.90)\end{array}$ & & \\
\hline Price cap (IV) & $\begin{array}{l}6.13^{*} \\
(1.96)\end{array}$ & & $\begin{array}{l}6.10^{*} \\
(2.04)\end{array}$ & $\begin{array}{c}1.79 \\
(2.77)\end{array}$ \\
\hline Duration since award & $\begin{array}{l}0.35^{*} \\
(0.08)\end{array}$ & $\begin{array}{l}0.26^{*} \\
(0.07)\end{array}$ & $\begin{array}{l}0.30 * \\
(0.08)\end{array}$ & $\begin{array}{l}0.29 * \\
(0.09)\end{array}$ \\
\hline Investment requirements & $\begin{array}{c}-0.36 * * * \\
(0.24) \\
\end{array}$ & $\begin{array}{l}-0.16 \\
(0.21)\end{array}$ & $\begin{array}{l}-0.15 \\
(0.23)\end{array}$ & $\begin{array}{l}-0.21 \\
(0.32)\end{array}$ \\
\hline Private financing & $\begin{array}{c}-0.99 * \\
(0.22)\end{array}$ & & & \\
\hline Private financing (IV) & & $\begin{array}{l}-3.20^{*} \\
(1.14) \\
\end{array}$ & $\begin{array}{l}-0.67 \\
(1.09) \\
\end{array}$ & $\begin{array}{l}-5.75^{*} \\
(2.69) \\
\end{array}$ \\
\hline Bureaucratic quality & $\begin{array}{l}-0.12 \\
(0.24) \\
\end{array}$ & $\begin{array}{c}0.18 \\
(0.22) \\
\end{array}$ & $\begin{array}{l}-0.02 \\
(0.27) \\
\end{array}$ & $\begin{array}{l}1.35^{*} \\
(0.67) \\
\end{array}$ \\
\hline $\begin{array}{l}\text { Minimum income guarantee } \\
\text { (IV) }\end{array}$ & & & & $\begin{array}{l}15.58^{*} \\
(7.61)\end{array}$ \\
\hline Election-1 & $\begin{array}{c}0.12 \\
(0.17) \\
\end{array}$ & $\begin{array}{c}0.06 \\
(0.19) \\
\end{array}$ & $\begin{array}{l}-0.01 \\
(0.27) \\
\end{array}$ & $\begin{array}{c}0.09 \\
(0.22) \\
\end{array}$ \\
\hline GDP growth -1 & $\begin{array}{l}-0.12 * \\
(0.03)\end{array}$ & $\begin{array}{l}-0.09 * \\
(0.03)\end{array}$ & $\begin{array}{l}-0.11^{*} \\
(0.04)\end{array}$ & $\begin{array}{l}-0.13^{*} \\
(0.04)\end{array}$ \\
\hline GDP growth -2 & $\begin{array}{c}-0.09 * * * \\
(0.04)\end{array}$ & $\begin{array}{l}-0.05 \\
(0.03)\end{array}$ & $\begin{array}{l}-0.08 \\
(0.05)\end{array}$ & $\begin{array}{l}-0.12 * \\
(0.05)\end{array}$ \\
\hline Transport sector dummy & $\begin{array}{l}-1.62 * \\
(0.51)\end{array}$ & $\begin{array}{l}-0.62 \\
(0.59)\end{array}$ & $\begin{array}{l}-1.61^{*} \\
(0.70)\end{array}$ & $\begin{array}{l}-2.03^{*} \\
(0.82)\end{array}$ \\
\hline Number of obs. & 1132 & 1132 & 1132 & 1132 \\
\hline Log Likelihood & -163.95 & -186.84 & -178.63 & -171.27 \\
\hline \multicolumn{5}{|c|}{ Marginal effects $(\mathrm{dy} / \mathrm{dx})^{\mathrm{a}}$} \\
\hline $\mathrm{y}=\operatorname{Pr}($ renegotiation=1) & 0.004 & 0.017 & 0.010 & 0.006 \\
\hline Existence of regulatory body & 0.003 & -0.065 & 0.012 & -0.238 \\
\hline Price cap & -0.081 & 0.006 & 0.167 & 0.029 \\
\hline Duration since award & 0.005 & 0.011 & 0.008 & 0.005 \\
\hline Investment requirements & -0.007 & -0.007 & -0.005 & -0.004 \\
\hline Private financing & -0.023 & -0.135 & -0.018 & -0.093 \\
\hline Bureaucratic quality & -0.002 & 0.008 & -0.001 & 0.022 \\
\hline Minimum income guarantee & & & & 0.252 \\
\hline Election-1 & 0.002 & 0.002 & 0.0002 & 0.001 \\
\hline GDP growth -1 & -0.002 & -0.003 & -0.003 & -0.002 \\
\hline GDP growth -2 & -0.001 & -0.002 & -0.002 & -0.002 \\
\hline Transport sector dummy & -0.085 & -0.192 & -0.138 & -0.165 \\
\hline
\end{tabular}

(a) For dummy variables, dy/dx is for discrete change from 0 to 1 . For continuous variables, it corresponds to an increase by 1 unit.

Standard errors in parenthesis are bootstrapped estimates based on 100 replications. The significance level $(1 \%(*)$, 5\% $(* *)$ and $10 \%(* * *))$ is assessed using the percentile confidence interval. For example, for the $95 \%$ interval, the bottom endpoint is the $2.5^{\text {th }}$ percentile and the upper endpoint is the $97.5^{\text {th }}$ percentile. If the confidence interval build in that way contains 0 , the coefficient is not significant. Non-normality of the distribution may explain that coefficients are deemed significant while having relatively large standard errors. 
Table 9: Random effect probit panel Additional results on institutional aspects

\begin{tabular}{|c|c|c|c|c|c|c|}
\hline & (1) & (2) & (3) & (4) & (5) & (6) \\
\hline Dependent variable & $\begin{array}{c}\text { Reneg. } \\
\text { initiated by } \\
\text { Govt }\end{array}$ & $\begin{array}{l}\text { Reneg. } \\
\text { Initiated by } \\
\text { Govt }\end{array}$ & $\begin{array}{l}\text { Reneg. } \\
\text { initiated by } \\
\text { Govt }\end{array}$ & $\begin{array}{c}\text { Reneg. } \\
\text { initiated by } \\
\text { Govt }\end{array}$ & $\begin{array}{l}\text { Reneg. } \\
\text { Initiated by } \\
\text { Govt }\end{array}$ & $\begin{array}{c}\text { Reneg. } \\
\text { initiated by } \\
\text { Govt }\end{array}$ \\
\hline $\begin{array}{l}\text { Existence of regulatory } \\
\text { body }\end{array}$ & $\begin{array}{l}-0.98^{*} \\
(0.29)\end{array}$ & $\begin{array}{l}-1.03^{*} \\
(0.30)\end{array}$ & $\begin{array}{l}-3.52^{*} \\
(0.67)\end{array}$ & $\begin{array}{l}-1.10^{*} \\
(0.30)\end{array}$ & $\begin{array}{c}0.47 \\
(0.40)\end{array}$ & $\begin{array}{l}-6.74^{*} \\
(1.75)\end{array}$ \\
\hline $\begin{array}{l}\text { Regulatory body is part } \\
\text { of the Govt. Ministry }\end{array}$ & $\begin{array}{l}5.16^{*} \\
(0.65)\end{array}$ & $\begin{array}{l}5.28^{*} \\
(0.65)\end{array}$ & & & & \\
\hline $\begin{array}{l}\text { Existence of reg. * } \\
\text { Corruption }\end{array}$ & & & $\begin{array}{l}1.22 * \\
(0.24)\end{array}$ & & & $\begin{array}{l}2.27 * \\
(0.58)\end{array}$ \\
\hline Price cap & $\begin{array}{c}0.22 \\
(0.37)\end{array}$ & $\begin{array}{c}0.21 \\
(0.38)\end{array}$ & $\begin{array}{l}-0.57 \\
(0.45)\end{array}$ & $\begin{array}{c}0.11 \\
(0.36)\end{array}$ & $\begin{array}{l}-0.49 \\
(0.44)\end{array}$ & $\begin{array}{c}-0.78^{* * *} \\
(0.46)\end{array}$ \\
\hline Duration since award & $\begin{array}{l}0.31^{*} \\
(0.05)\end{array}$ & $\begin{array}{l}0.29 * \\
(0.05)\end{array}$ & $\begin{array}{l}0.38^{*} \\
(0.06)\end{array}$ & $\begin{array}{l}0.32 * \\
(0.05)\end{array}$ & $\begin{array}{l}0.39 * \\
(0.06)\end{array}$ & $\begin{array}{l}0.41^{*} \\
(0.06)\end{array}$ \\
\hline $\begin{array}{l}\text { Investment } \\
\text { requirements }\end{array}$ & $\begin{array}{c}-0.37 * * * \\
(0.20)\end{array}$ & $\begin{array}{c}-0.44^{* *} \\
(0.20)\end{array}$ & $\begin{array}{l}-0.60^{*} \\
(0.22)\end{array}$ & $\begin{array}{c}-0.34^{* * * *} \\
(0.21)\end{array}$ & $\begin{array}{c}-0.53^{* *} \\
(0.22)\end{array}$ & $\begin{array}{l}-0.67^{*} \\
(0.23)\end{array}$ \\
\hline Private financing & $\begin{array}{l}-1.25^{*} \\
(0.21)\end{array}$ & $\begin{array}{l}-1.19^{*} \\
(0.21)\end{array}$ & $\begin{array}{l}-0.98^{*} \\
(0.21)\end{array}$ & $\begin{array}{l}-1.27^{*} \\
(0.21)\end{array}$ & $\begin{array}{l}-1.02^{*} \\
(0.21)\end{array}$ & $\begin{array}{l}-0.94^{*} \\
(0.21)\end{array}$ \\
\hline Bureaucratic quality & $\begin{array}{l}-0.53^{*} \\
(0.14)\end{array}$ & $\begin{array}{l}-0.57^{*} \\
(0.14)\end{array}$ & $\begin{array}{l}-0.85^{*} \\
(0.18)\end{array}$ & $\begin{array}{c}-0.35^{* *} \\
(0.16)\end{array}$ & $\begin{array}{l}-0.83^{*} \\
(0.18)\end{array}$ & $\begin{array}{l}-1.04^{*} \\
(0.20)\end{array}$ \\
\hline Corruption & & & & & $\begin{array}{l}1.53^{*} \\
(0.35)\end{array}$ & $\begin{array}{l}-0.32 \\
(0.56)\end{array}$ \\
\hline Election-1 & $\begin{array}{c}0.22 \\
(0.16)\end{array}$ & & $\begin{array}{c}0.28 \\
(0.17)\end{array}$ & $\begin{array}{l}2.54^{* *} \\
(1.08)\end{array}$ & $\begin{array}{l}2.86^{*} \\
(1.01)\end{array}$ & $\begin{array}{l}3.24 * * \\
(1.29)\end{array}$ \\
\hline $\begin{array}{l}\text { Election-1* } \\
\text { Bureaucratic quality }\end{array}$ & & & & $\begin{array}{c}-0.71^{* *} \\
(0.33)\end{array}$ & & \\
\hline Election-1 $*$ Corruption & & & & & $\begin{array}{l}-0.89^{*} \\
(0.33)\end{array}$ & $\begin{array}{c}-1.01^{* *} \\
(0.43)\end{array}$ \\
\hline $\begin{array}{l}\text { Effective Political } \\
\text { change -1 }\end{array}$ & & $\begin{array}{c}0.70^{* * *} \\
(0.41)\end{array}$ & & & & \\
\hline GDP growth -1 & $\begin{array}{l}-0.07 * \\
(0.02)\end{array}$ & $\begin{array}{l}-0.08^{*} \\
(0.02)\end{array}$ & $\begin{array}{l}-0.14^{*} \\
(0.03)\end{array}$ & $\begin{array}{l}-0.07 * \\
(0.02)\end{array}$ & $\begin{array}{l}-0.13^{*} \\
(0.03)\end{array}$ & $\begin{array}{l}-0.17^{*} \\
(0.03)\end{array}$ \\
\hline GDP growth -2 & $\begin{array}{c}-0.06^{* *} \\
(0.03)\end{array}$ & $\begin{array}{c}-0.06^{* *} \\
(0.03)\end{array}$ & $\begin{array}{c}-0.08^{* *} \\
(0.03)\end{array}$ & $\begin{array}{l}-0.04 \\
(0.03)\end{array}$ & $\begin{array}{c}-0.07^{* *} \\
(0.03)\end{array}$ & $\begin{array}{l}-0.11^{*} \\
(0.03)\end{array}$ \\
\hline $\begin{array}{l}\text { Transport sector } \\
\text { dummy }\end{array}$ & $\begin{array}{l}-0.20 \\
(0.30)\end{array}$ & $\begin{array}{l}-0.06 \\
(0.31)\end{array}$ & $\begin{array}{l}-1.07^{*} \\
(0.36)\end{array}$ & $\begin{array}{l}-0.14 \\
(0.32)\end{array}$ & $\begin{array}{l}-1.50^{*} \\
(0.39)\end{array}$ & $\begin{array}{c}-1.00^{* *} \\
(0.40)\end{array}$ \\
\hline Number of obs. & 1127 & 1127 & 1132 & 1132 & 1132 & 1132 \\
\hline Log Likelihood & -171.44 & -170.51 & -157.90 & -170.90 & -159.73 & -152.22 \\
\hline
\end{tabular}

\begin{tabular}{|c|c|c|c|c|c|c|}
\hline \multicolumn{7}{|c|}{ Marginal effects (dy/dx) ${ }^{\mathrm{a}}$} \\
\hline$y=\operatorname{Pr}($ renegotiation=1) & 0.006 & 0.006 & 0.003 & 0.008 & 0.002 & 0.001 \\
\hline $\begin{array}{l}\text { Existence of regulatory } \\
\text { body }\end{array}$ & -0.029 & -0.033 & -0.324 & -0.044 & -0.003 & -0.909 \\
\hline $\begin{array}{l}\text { Regulatory body is part } \\
\text { of the Govt. Ministry }\end{array}$ & 0.010 & 0.011 & & & & \\
\hline $\begin{array}{l}\text { Existence of reg. * } \\
\text { Corruption }\end{array}$ & & & 0.011 & & & 0.008 \\
\hline Price cap & 0.003 & 0.003 & -0.010 & -0.002 & -0.007 & -0.008 \\
\hline Duration since award & 0.005 & 0.005 & 0.003 & 0.007 & 0.003 & 0.002 \\
\hline $\begin{array}{l}\text { Investment } \\
\text { requirements }\end{array}$ & -0.009 & -0.012 & -0.010 & -0.010 & -0.007 & -0.005 \\
\hline Private financing & -0.043 & -0.041 & -0.016 & -0.054 & -0.015 & -0.007 \\
\hline Bureaucratic quality & -0.009 & -0.010 & -0.008 & -0.008 & -0.006 & -0.004 \\
\hline Corruption & & & & & 0.012 & -0.001 \\
\hline Election-1 & 0.004 & & 0.003 & 0.255 & 0.196 & 0.200 \\
\hline $\begin{array}{l}\text { Election-1* } \\
\text { Bureaucratic quality }\end{array}$ & & & & -0.016 & & \\
\hline Election-1 * Corruption & & & & & -0.006 & -0.004 \\
\hline $\begin{array}{l}\text { Effective Political } \\
\text { change }-1\end{array}$ & & 0.006 & & & & \\
\hline GDP growth -1 & -0.001 & -0.001 & -0.001 & -0.002 & -0.001 & -0.001 \\
\hline GDP growth -2 & -0.001 & -0.001 & -0.001 & -0.001 & -0.001 & -0.0004 \\
\hline $\begin{array}{l}\text { Transport sector } \\
\text { dummy }\end{array}$ & -0.004 & -0.001 & -0.026 & -0.004 & 0.048 & -0.010 \\
\hline
\end{tabular}

(a) For dummy variables, dy/dx is for discrete change from 0 to 1 . For continuous variables, it corresponds to an increase by 1 unit.

Standard errors in parenthesis. Coefficients significant at the $1 \%(*), 5 \%\left({ }^{* *}\right)$ and $10 \%\left({ }^{* * *}\right)$ level. 
Table 10: Random effect probit panel

Robustness checks

\begin{tabular}{|c|c|c|c|c|c|c|c|}
\hline & (1) & (2) & (3) & (4) & (5) & (6) & (7) \\
\hline Dependent variable & $\begin{array}{l}\text { Reneg. } \\
\text { Initiated } \\
\text { by Govt or } \\
\text { both }\end{array}$ & $\begin{array}{l}\text { Reneg. } \\
\text { Initiated } \\
\text { by Govt or } \\
\text { both }\end{array}$ & $\begin{array}{l}\text { Reneg. } \\
\text { Initiated } \\
\text { by Govt or } \\
\text { both }\end{array}$ & $\begin{array}{l}\text { Reneg. } \\
\text { Initiated } \\
\text { by Govt or } \\
\text { both }\end{array}$ & $\begin{array}{l}\text { Reneg. } \\
\text { Initiated } \\
\text { by Govt or } \\
\text { both }\end{array}$ & $\begin{array}{l}\text { Reneg. } \\
\text { Initiated } \\
\text { by Govt or } \\
\text { both }\end{array}$ & $\begin{array}{l}\text { Reneg. } \\
\text { Initiated } \\
\text { by Govt or } \\
\text { both }\end{array}$ \\
\hline $\begin{array}{l}\text { Existence of regulatory } \\
\text { body }\end{array}$ & $\begin{array}{l}-0.01 \\
(0.18)\end{array}$ & $\begin{array}{l}-0.56 * * \\
(0.24)\end{array}$ & $\begin{array}{l}-0.78^{*} \\
(0.30)\end{array}$ & $\begin{array}{c}-0.50^{* *} \\
(0.24)\end{array}$ & $\begin{array}{c}0.13 \\
(0.31)\end{array}$ & $\begin{array}{c}-0.66^{* *} \\
(0.26)\end{array}$ & $\begin{array}{l}-0.59^{*} \\
(0.26)\end{array}$ \\
\hline Price cap & & $\begin{array}{c}0.01 \\
(0.28)\end{array}$ & $\begin{array}{c}-0.73^{* *} \\
(0.35)\end{array}$ & $\begin{array}{l}-0.34 \\
(0.34)\end{array}$ & $\begin{array}{l}-0.36 \\
(0.31)\end{array}$ & $\begin{array}{l}-0.48 \\
(0.32)\end{array}$ & $\begin{array}{c}0.17 \\
(0.29)\end{array}$ \\
\hline Duration since award & $\begin{array}{l}0.12 * \\
(0.03)\end{array}$ & $\begin{array}{l}0.23^{*} \\
(0.04)\end{array}$ & $\begin{array}{l}0.20^{*} \\
(0.04)\end{array}$ & $\begin{array}{l}0.23^{*} \\
(0.04)\end{array}$ & $\begin{array}{l}0.25 * \\
(0.04)\end{array}$ & $\begin{array}{l}0.20^{*} \\
(0.04)\end{array}$ & $\begin{array}{l}0.21^{*} \\
(0.04)\end{array}$ \\
\hline $\begin{array}{l}\text { Investment } \\
\text { requirements }\end{array}$ & & $\begin{array}{l}-0.19 \\
(0.18)\end{array}$ & $\begin{array}{l}-0.01 \\
(0.21)\end{array}$ & $\begin{array}{l}-0.15 \\
(0.18)\end{array}$ & $\begin{array}{l}-0.25 \\
(0.18)\end{array}$ & $\begin{array}{l}-0.24 \\
(0.19)\end{array}$ & $\begin{array}{l}-0.21 \\
(0.19)\end{array}$ \\
\hline Private financing & & $\begin{array}{l}-1.06^{*} \\
(0.17)\end{array}$ & $\begin{array}{l}-0.37 \\
(0.23)\end{array}$ & $\begin{array}{l}-0.96^{*} \\
(0.18)\end{array}$ & $\begin{array}{l}-0.87^{*} \\
(0.17)\end{array}$ & $\begin{array}{l}-0.90^{*} \\
(0.18)\end{array}$ & $\begin{array}{l}-0.96^{*} \\
(0.18)\end{array}$ \\
\hline Bureaucratic quality & $\begin{array}{l}-0.51^{*} \\
(0.10)\end{array}$ & $\begin{array}{l}-0.43^{*} \\
(0.12)\end{array}$ & $\begin{array}{c}-0.29 * * \\
(0.14)\end{array}$ & $\begin{array}{l}-0.46^{*} \\
(0.12)\end{array}$ & $\begin{array}{l}-0.55^{*} \\
(0.13)\end{array}$ & $\begin{array}{l}-0.35^{*} \\
(0.13)\end{array}$ & $\begin{array}{l}-0.36^{*} \\
(0.13)\end{array}$ \\
\hline Arbitration process & & & $\begin{array}{l}-1.76^{*} \\
(0.34)\end{array}$ & & & & \\
\hline Bidding process & & & & $\begin{array}{c}0.62^{* * *} \\
(0.35)\end{array}$ & & & \\
\hline Corruption & & & & & $\begin{array}{l}0.50^{*} \\
(0.15)\end{array}$ & & \\
\hline $\begin{array}{l}\text { Minimum income } \\
\text { guarantee }\end{array}$ & & & & & & $\begin{array}{l}0.92 * \\
(0.24)\end{array}$ & \\
\hline Award criteria & & & & & & & $\begin{array}{l}-0.69 * \\
(0.25)\end{array}$ \\
\hline Election-1 & $\begin{array}{l}0.51^{*} \\
(0.11)\end{array}$ & $\begin{array}{l}0.32 * * \\
(0.14)\end{array}$ & $\begin{array}{l}0.42^{*} \\
(0.15)\end{array}$ & $\begin{array}{l}0.31 * * \\
(0.14)\end{array}$ & $\begin{array}{l}0.31 * * \\
(0.14)\end{array}$ & $\begin{array}{l}0.35^{* *} \\
(0.14)\end{array}$ & $\begin{array}{l}0.34^{* *} \\
(0.14)\end{array}$ \\
\hline GDP growth -1 & $\begin{array}{c}-0.04 * * \\
(0.02)\end{array}$ & $\begin{array}{c}-0.03^{* * * *} \\
(0.02)\end{array}$ & $\begin{array}{l}-0.06^{*} \\
(0.02)\end{array}$ & $\begin{array}{c}-0.04^{* *} \\
(0.02)\end{array}$ & $\begin{array}{c}-0.05^{* *} \\
(0.02)\end{array}$ & $\begin{array}{c}-0.04 * * \\
(0.02)\end{array}$ & $\begin{array}{c}-0.04^{* * * *} \\
(0.02)\end{array}$ \\
\hline GDP growth -2 & $\begin{array}{l}-0.02 \\
(0.02)\end{array}$ & $\begin{array}{l}-0.03 \\
(0.03)\end{array}$ & $\begin{array}{l}-0.04 \\
(0.03)\end{array}$ & $\begin{array}{l}-0.03 \\
(0.03)\end{array}$ & $\begin{array}{l}-0.03 \\
(0.03)\end{array}$ & $\begin{array}{c}-0.05^{* * *} \\
(0.03)\end{array}$ & $\begin{array}{l}-0.04 \\
(0.03)\end{array}$ \\
\hline $\begin{array}{l}\text { Transport sector } \\
\text { dummy }\end{array}$ & $\begin{array}{l}-0.82 * \\
(0.18)\end{array}$ & $\begin{array}{l}-0.23^{*} \\
(0.27)\end{array}$ & $\begin{array}{c}0.48 \\
(0.34)\end{array}$ & $\begin{array}{l}-0.28 \\
(0.26)\end{array}$ & $\begin{array}{c}-0.76^{* *} \\
(0.30)\end{array}$ & $\begin{array}{c}-0.75^{* *} \\
(0.32)\end{array}$ & $\begin{array}{l}-0.01 \\
(0.29)\end{array}$ \\
\hline Number of obs. & 1267 & 1132 & 1100 & 1132 & 1132 & 1127 & 1132 \\
\hline Log Likelihood & -312.83 & -226.68 & -206.30 & -225.02 & -220.66 & -218.31 & -222.24 \\
\hline
\end{tabular}

\begin{tabular}{|c|c|c|c|c|c|c|c|}
\hline \multicolumn{8}{|c|}{ Marginal effects $(\mathrm{dy} / \mathrm{dx})^{\mathrm{a}}$} \\
\hline $\mathrm{y}=\operatorname{Pr}($ renegotiation $=1)$ & 0.054 & 0.028 & 0.015 & 0.027 & 0.025 & 0.021 & 0.024 \\
\hline $\begin{array}{l}\text { Existence of regulatory } \\
\text { body }\end{array}$ & -0.011 & -0.045 & -0.039 & -0.037 & -0.007 & -0.042 & -0.041 \\
\hline Price cap & & -0.001 & -0.051 & -0.028 & -0.028 & -0.035 & 0.008 \\
\hline Duration since award & 0.013 & 0.015 & 0.008 & 0.015 & 0.015 & 0.010 & 0.012 \\
\hline $\begin{array}{l}\text { Investment } \\
\text { requirements }\end{array}$ & & -0.014 & $\begin{array}{c}-0.0003 \\
\end{array}$ & -0.010 & -0.017 & -0.014 & -0.014 \\
\hline Private financing & & -0.099 & -0.016 & -0.083 & -0.069 & -0.062 & -0.076 \\
\hline Bureaucratic quality & -0.055 & -0.028 & -0.011 & -0.029 & -0.032 & -0.018 & -0.020 \\
\hline Arbitration process & & & -0.141 & & & & \\
\hline Bidding process & & & & 0.027 & & & \\
\hline Corruption & & & & & 0.029 & & \\
\hline $\begin{array}{l}\text { Minimum income } \\
\text { guarantee }\end{array}$ & & & & & & 0.074 & \\
\hline Award criteria & & & & & & & -0.034 \\
\hline Election-1 & 0.065 & 0.023 & 0.019 & 0.022 & 0.020 & 0.020 & 0.021 \\
\hline GDP growth -1 & -0.004 & -0.002 & -0.0002 & -0.002 & -0.003 & -0.002 & -0.002 \\
\hline GDP growth -2 & -0.002 & -0.002 & -0.0002 & -0.002 & -0.002 & -0.002 & -0.002 \\
\hline $\begin{array}{l}\text { Transport sector } \\
\text { dummy }\end{array}$ & -0.126 & 0.017 & 0.014 & -0.020 & -0.068 & -0.058 & -0.001 \\
\hline
\end{tabular}

(a) For dummy variables, dy/dx is for discrete change from 0 to 1 . For continuous variables, it

corresponds to an increase by 1 unit.

Standard errors in parenthesis. Coefficients significant at the $1 \%\left({ }^{*}\right), 5 \%\left({ }^{* *}\right)$ and $10 \%\left({ }^{* * *}\right)$ level. 